\title{
21. Yüzyıl Becerileri Açısından Ortaokul Türkçe Dersi Öğretim Programı*
}

\section{Secondary School Turkish Course Curriculum in Terms of 21st \\ Century Skills}

\section{Gürcü Erdamar, Meryem Barası}

\begin{tabular}{l}
\hline Yazar Bilgileri \\
\hline Gürcü Erdamar \\
Prof. Dr., Gazi Üniversitesi, \\
Gazi Eğitim Fakültesi, Eğitim \\
Bilimleri, gurkoc@gazi.edu.tr
\end{tabular}

\section{Meryem Barası}

Türkçe Öğretmeni, Millî Eğitim

Bakanlı̆̆ı,

meryembarasi@gmail.com

\section{ÖZ}

Bu araştırmanın amacı 2018 yılı ortaokul Türkçe Dersi Öğretim Programı́nı 21. yüzyıl becerileri açısından incelemektir. Bu doğrultuda; 2018 yılı ortaokul Türkçe Dersi Öğretim Programı'nda 21. yüzyıl becerilerine yer verilme durumu araştırılmıştır. Araştırmanın modeli nitel araştırma yöntemlerinden doküman analizi incelemesidir. 2018 Ortaokul Türkçe Dersi Öğretim Programı́nın tamamı çalışmaya dâhil edilmiştir. Doküman analizinde Partnership for 21 Century Skills (P21) sınıflandırması dikkate alınarak oluşturulmuş 21. yüzyıl becerileri seçilmiştir. Bu beceriler öğrenme ve yenilik, bilgi, medya ve teknoloji ve yaşam ve kariyer beceriler olmak üzere üç alanda sınıflanmıştır. Doküman analizine göre Türkçe Dersi Öğretim Programı'nda en çok yer verilen beceriler; genel amaçlarda (özel amaç, yetkinlik, kazanım) iletişim, eleştirel düşünme ve karar verme; içerikte iletişim, iş birliği problem çözme; öğrenme öğretme süreçlerinde eleştirel düşünme, üretkenlik, medya okuryazarlığı, öğrenmeyi öğrenme; ölçme ve değerlendirme ögelerinde öğrenmeyi öğrenme, medya okuryazarlığı, yaratıcılık, öz yönlendirme becerileridir. En az yer verilen beceriler ise genel amaçlarda yenilikçilik, iş birliği, medya okuryazarlığı; içerikte eleştirel düşünme, karar verme, medya okuryazarlığı; öğrenme-öğretme süreçlerinde hesap verebilirlik, liderlik, yenilikçilik, esneklik ve uyum; ölçme ve değerlendirmede ise iletişim, iş birliği, bilgi okuryazarlığı, liderlik ve sorumluluk alma becerileridir.

Makale Bilgileri
Anahtar Kelimeler
Türkçe Dersi Öğretim Programı
Ortaokul
21. Yüzyıl Becerileri
Doküman Analizi

\section{ABSTRACT}

The aim of this research is to examine the 2018 secondary school Turkish curriculum in terms of 21st-century skills. In accordance with this purpose, the situation of 21st-century skills in the 2018 Turkish class curriculum was investigated. As a qualitative research method, document analysis method was used for examining the curriculum in terms of 21stcentury skills, and the sample document in this study is the Turkish class curriculum. In the study, document analysis was used as a qualitative data collection tool in order to examine the Turkish course curriculum. For this purpose, the entire 2018 secondary school Turkish class curriculum was examined. In the document analysis, benchmark skills are created according to the "Partnership for 21 Century Skills" (P21) classification. The skills are seen to be composed of three main skill fields: learning and innovation skills, knowledge, media and technology skills, and life and career skills. According to the document analysis, the skills mostly included in the Turkish course curriculum; communication, critical thinking, and decision making in general purposes (specific purpose, competence, achievement); problem solving, communication and collaboration in content; critical thinking, productivity, media literacy, learning to learn in teaching and learning processes; creativity, media literacy, learning to learn and self-direction skills in measurement and evaluation items. The least frequently mentioned skills are innovativeness, collaboration, media literacy in general purpose; critical thinking, decision making, media literacy in content; accountability, leadership, innovation, flexibility, and adaptability in learning-teaching processes; communication, cooperation, information literacy, leadership, and taking responsibility skills in assessment and evaluation.

*Bu çalışma birinci yazar danışmanlığında ikinci yazar tarafından yürütülen yüksek lisans tezinden üretilmiştir. 


\section{Giriş}

Bilgi ve iletişim teknolojilerinin hızlı bir şekilde gelişmesiyle dünyanın herhangi bir yerinde olan bir gelişmenin bütün insanları etkileyebildiği ve bilgiye ulaşmanın çok kolaylaştığı günümüzde; bu bilgilerin nasıl yorumlanacağı, değişen şartlara nasıl uyum sağlanacağı önem kazanmaktadır. Korkmaz ve Kalaycı'nın (2019) belirttiği üzere bilginin küreselleşmesi; toplum, kültür, siyaset, ekonomi, teknoloji, endüstri alanlarında yaşanan gelişim, kalite anlayışındaki değişim, ulusal ve uluslararası rekabet ve yeni meslek alanlarının bireylerden talep ettiği bilgi, beceri ve yetkinlikler eğitim-öğretimde köklü değişmelere neden olmaktadır.

Günümüzde bir önceki yüzyılda insanlar tarafından yapılan birçok iş, teknoloji sayesinde çok kısa sürelerde yapılabilmektedir. Okuma, yazma, matematik gibi temel becerilerde iyi olmak, iş dünyasındaki çalışan ihtiyacına cevap vermemektedir. Düşük maaşlı işlerde bile bireylerin karşılaştıkları sorunlara çözüm üretebilme becerisine sahip olmaları tercih edilmektedir (Marzano ve Heflebower, 2012; Wagner, 2008). Benzer tespitte bulunan Keskin (2012) de çocuğun hayata atılma aşamasına geldiğinde birçok işin bilgisayarlar ile yapıldığını görerek üretken düşünmesi gerektiğini anlayacağını ve bulunduğu ortamın hangi alanda olursa olsun kendisinden bir farklılık yaratmasını bekleyeceğini vurgulamaktadır. Bunun doğal ve zorunlu bir sonucu olarak yaratıcılık ve sezgisel gücün öneminin artacağını ifade etmiştir. Başka bir deyişle bu yüzyılda insana düşen en önemli görev özgün, yeni, yaratıc1, eleştirel düşünmektir.

Gelişen dünyaya uyum sağlayabilmek için yaratıcı, eleştirel, özgün düşünme, iletişim ve iş birliği, liderlik, zaman yönetimi, problem çözme, karar verme, inovasyon gibi 21. yüzyıl becerilerine ihtiyaç vardır. Yapılan çalışmalarda bu beceriler 21. yüzyıl becerileri olarak adlandırılmaktadır. Farklı ülkelerden bilim insanları bu becerileri saptamaya çalışmış ve eğitim programlarına dahil edilmesi gerektiği konusunda görüş birliğine varmışlardır (Fadel, Bialik ve Trilling, 2015; Kereluik, Mishra, Fahnoe ve Terry, 2013; Koening, 2011; Organisation for Economic Co-operation and Development [OECD], 2012; Partnership for 21 Century Skills [P21], 2015; Schleicher, 2012). Dünyada çevre, toplum, teknoloji ve ekonomik yapı sürekli değişirken bu değişime ayak uydurmak için 21. yüzyıl becerilerine göre insan yetiştirme konusunda düzenlemeler ve değişiklikler yapılması gerekmektedir (Kay, 2010; Marzano ve Heflebower, 2012; Y1lmaz, 2016). Çocuklara sadece okul içindeki eğitim faaliyetlerinde değil, farklı ortamlarda da özgün düşünme becerilerini geliştirecek görevler verilmeli ve bu tür öğrenme yaşantıları için fırsatlar tanınmalıdır.

Alanyazında 21. yüzyıl becerileriyle ilgili farklı sinıflamalar bulunmaktadır. ATC21S projesi kapsamında 60 kurumdan 250'den fazla araştırmacı bir araya gelerek 21. yüzyıl becerilerini düşünme yolları, çalışma yolları, çalışma araçları ve yaşam becerileri başlıklarında toplamıştır (OECD, 2012, s. 34). Kereluik vd.'ne (2013) göre 21. yüzyıl becerileri; “temel, değişim ve insancl bilgiler" dir. Fadel vd. 
(2015) 21. yüzyıl eğitiminin boyutlarını "bilgi, beceri, karakter ve meta öğrenme" olarak tanımlamıştır. National Research Council'a (NRC, 2011) göre 21. yüzyıl becerileri bilişsel beceriler, kişiler arası beceriler ve içsel becerilerdir. Lai ve Viering (2012), 21. yüzyıl becerilerini eleştirel düşünme, yaratıcılık, iş birliği, motivasyon, üst bilişsel becerileri olarak ele almaktadır. Dikkat çeken bir diğer sinıflandırmaya göre (P21, 2015) 21. yüzyıl becerisi "bireylerin iş ve yaşamda başarılı olmak için ustalaşması gereken beceri, bilgi ve uzmanlık" olarak tanımlanmaktadır. Bu beceriler "Öğrenme ve Yenilik", "Bilgi, Medya ve Teknoloji" ile "Yaşam ve Kariyer" becerileri olmak üzere üç ana başlık altında toplanmıştır. Bu beceriler bireylerin zorlu iş ve yaşam koşullarıyla güçlü biçimde mücadele etmesini desteklemeleri bakımından önem taşımaktadır.

21. yüzyıl becerileri hem dünyada hem de ülkemizde öğretim programlarına dahil edilmeye çalışılmaktadır. Ülkemizde 2005 yılından bu yana tüm öğretim programlarında öğrencilere kazandırılması gereken sekiz temel beceri yer almıştır. Bu beceriler "eleştirel düşünme, yaratıcı düşünme, iletişim, araştırma-sorgulama, problem çözme becerisi, bilgi teknolojilerini kullanma, girişimcilik, Türkçeyi doğru, etkili ve güzel kullanma" becerileridir (Milli Eğitim Bakanlığı [MEB], 2005). Sözü edilen bu becerilerin, 21. yüzyıl becerileri ile yakından ilgili oldukları görülmektedir. 2005 yılından günümüze kadar geliştirilen Türkçe, matematik, fen bilimleri, yabancı dil, sosyal bilgiler öğretim programlarında ortak olarak kazandırılması hedeflenen temel beceriler yer almaktadır. 21. yüzyıl becerilerinin ilişkilendirilebileceği en önemli derslerden birisi de Türkçedir. Çünkü Türkçe dersi sadece temel dil becerilerini değil, düşünme becerilerini de geliştirmektedir (Demirel, 1999; Öz, 2001; Sever, 2000). Türkçe dersi ile hem dili keşfetme ve giderek zenginleşen bir çizgide onu kullanma, estetik haz oluşturma, değerler sistemi yaratma hem de bilginin kendisinden çok bilgileri ilişkilendirme, düzenleme ve kullanılır hâle getirme sağlanabilmektedir (Cemiloğlu, 2004, s. 4-22). Başka bir deyişle Türkçe dersi, öğrencilerin dili kullanırken hem iletişim, iş birliği, eleştirel ve yaratıcı düşünme becerilerinin; kültür aktarımı sağlanırken araştırma, inceleme ve karar verme becerilerinin; değerler sistemi oluşturulurken liderlik, sorumluluk, öz yönlendirme becerilerinin; aynı zamanda medya ve iletişim teknolojileriyle iç içe olduğu için bilgi okuryazarlığı, medya okuryazarlığı becerilerinin geliştirilmesinde önemli rol oynamaktadır.

2009 yılı Türkçe öğretim programında temel beceriler başlığı altında yer alan beceriler, 2015 Türkçe öğretim programında temel beceriler başlı̆̆ kaldırılarak programın genel amaçlarında ifade edilmiştir. 2017 Türkçe Dersi Öğretim Programı́nda başlık açılmaksızın sekiz anahtar yetkinlik ile "ana dilde iletişim, yabancı dillerde iletişim, matematiksel yetkinlik ve bilim/teknolojide temel yetkinlikler, dijital yetkinlik, öğrenmeyi öğrenme, sosyal ve vatandaşlıkla ilgili yetkinlikler, inisiyatif alma ve girişimcilik, kültürel farkındalık ve ifade" becerilerine yer verilmiş, 2017 programında yer alan anahtar yetkinliklerin 2018 ve 2019 Türkçe Dersi Öğretim Programı'nda da “yetkinlikler” başlığı 
altında verildiği görülmüştür. Kalaycı ve Yıldırım (2020) 2009, 2017 ve 2019 Türkçe dersi öğretim programlarını inceledikleri çalışmalarında 2009 programında belirtilen temel becerilerin 2017 ve 2019 programlarında bulunmadığını, 2009 programında bulunmayan temel yeterlilik alanlarının 2017 ve 2019 programlarına eklendiğini saptamıştır.

Alanyazın incelendiğinde Türkçe Dersi Öğretim Programı'nın ögelerinin analiz edildiği ve Türkçe Dersi Öğretim Programı'na yönelik öğretmenlerin görüşlerinin alındığı (Aktaş ve Yurt, 2016; Altunkeser ve Coşkun, 2016, 2017; Alver ve Sancak, 2016; Bağc1-Ayrancı ve Mutlu, 2017; Bayburtlu, 2015; Epçaçan ve Erzen, 2008; Şahin, 2007; Şahin ve Bayramoğlu, 2016; Yıldız ve İzalan, 2016) çalışmalar bulunmaktadır. Türkçe Dersi Öğretim Programı'nı 21. yüzyıl becerileri açısından inceleyen çalışma sayısı ise oldukça azdır (Bal, 2018; Belet-Boyacı ve Güner-Özer, 2019; Kayhan, Altun ve Gürol, 2019; Kurudayığlu ve Soysal, 2019). Bu çalışmalardan bazılarının tek bir sınıf düzeyini (Kayhan vd., 2019) bazılarının da programın tek bir ögesini incelediği (Bal, 2018; Kurudayığlu ve Soysal, 2019) görülmüştür. Ortaokul Türkçe Dersi Öğretim Programı'nın tüm ögelerinin 21. yüzyıl becerileri açısından bir bütün olarak incelenmesi bu çalışmanın önemini artırmaktadır. Araştırma sonuçlarının MEB'e ve program geliştirme uzmanlarına, program geliştirme sürecinde 21. yüzyıl becerilerinin kazandırılması için eğitim programının hangi ögesinde ne tür değişiklikler yapılması gerektiği konusunda gerekli düzenlemeler için bir veri kaynağı olacağı umulmaktadır. Bu nedenlerle 21. yüzyıl becerileri ve Türkçe Dersi Öğretim Programı, araştırmaya konu olmuştur.

Bu araştırmanın amacı 2018 yılı ortaokul (5, 6, 7 ve 8. sinıflar) Türkçe Dersi Öğretim Programı'nın 21. yüzyıl becerileri açısından incelenmesidir. Bu amaca bağlı olarak araştırmanın alt problemleri şunlardır:

Ortaokul Türkçe Dersi Öğretim Programı'nın;

1. Amaçlarında (kazanım, özel amaç, yetkinlik) 21. yüzyıl becerilerine yer verilme durumu nedir?

2. İçeriğinde 21. yüzyıl becerilerine yer verilme durumu nedir?

3. Öğrenme-öğretme sürecinde 21. yüzyıl becerilerine yer verilme durumu nedir?

4. Ölçme-değerlendirme sürecinde 21. yüzyıl becerilerine yer verilme durumu nedir?

\section{Yöntem}

Araştırmada, 2018 yılı Ortaokul Türkçe Dersi Öğretim Programı́nın 21. yüzyıl becerileri açısından değerlendirilmesinde betimsel model kullanılmıştır. Betimsel modelde araştırmaya konu olan olay, birey ya da nesne mevcut koşulları içinde olduğu şekliyle hiçbir değişiklik yapılmadan gözlemlenerek tanımlanmaya çalışılır (Karasar, 2017). Betimsel araştırmalar incelenen durumu mümkün olduğunca tam ve dikkatli bir şekilde tanımlar (Büyüköztürk, Kılıç-Çakmak, Akgün, 
Karadeniz ve Demirel, 2016). Türkçe Dersi Öğretim Programı, 21. yüzyıl becerileri açısından incelenirken nitel araştırma yöntemlerinden doküman incelemesinden yararlanılmıştır. "Dokümanlar, nitel araştırmalarda etkili bir şekilde kullanılması gereken önemli bilgi kaynaklarıdır." (Yıldırım ve Şimşek, 2018, s. 190). Buna göre, Türkçe öğretim programının amaç, içerik, öğrenme-öğretme süreçleri, ölçme ve değerlendirme boyutları 21. yüzyıl becerileri açısından analiz edilmiştir.

\section{Evren ve Örneklem}

Araştırmanın evreni ortaokul Türkçe dersi $(5,6,7$, ve 8. sınıf) öğretim programıdır. Bu açıdan evrenin tamamı incelemeye alınmıştır. Araştırmada kullanılan doküman, Talim ve Terbiye Kurulu Başkanlığının resmî web sayfasından elde edilmiştir (http://mufredat.meb.gov.tr/Programlar.aspx). Genel olarak bütün derslerin öğretim programı incelendiğinde öğretim programının amaçları, perspektifi, bu perspektif doğrultusunda hazırlanan değerler ve yetkinlikler bölümü, öğretim programlarında ölçme ve değerlendirme, bireysel gelişim ve öğretim programları bölümlerine yer verilmiştir. Türkçe Dersi Öğretim Programı́nın yapısı ise; Türkçe dersinin özel amaçları, öğrenmeöğretme yaklaşımı, ölçme değerlendirme yaklaşımı, uygulamada dikkat edilecek hususlar, beceri alanları, kazanımlar ve açıklamaları şeklinde yapılandırılmıştır. Türkçe Dersi Öğretim Programı́nın uygulanmasında dikkat edilecek hususlar başlığı altında; ilk okuma yazma süreci, temalara, metin sayısı ve metin türlerine yönelik açıklamalar yer almaktadır.

\section{Veri Toplama Araçları}

Ortaokul Türkçe Dersi Öğretim Programı́nı incelemek için P21 sınıflaması dikkate alınarak oluşturulmuş beceriler dikkate alınmıştır. Farklı kaynaklarca en çok tekrar eden becerileri bünyesinde bulundurduğu için P21 sınıflandırmasının kullanılmasına karar verilmiştir. En çok tekrar eden 21. yüzyıl becerilerinin iletişim, problem çözme, eleştirel düşünme, yaratıcılık, karar verme, iş birliği, dijital okur-yazarlık (Ekici, Abide, Canbolat ve Öztürk, 2017; EnGauge, 2003; Fadel vd., 2015; Marzona, 2012; OECD, 2012) olduğu görülmektedir. P21 sınıflamasında yer alan 21. yüzyıl becerileri beceriler, öğrenme ve yenilik başlığı altında problem çözme, yaratıcılık, yenilikçilik, iletişim, iş birliği, eleştirel düşünme, karar verme, öğrenmeyi öğrenme; bilgi, medya ve teknoloji becerileri başlığ1 altında bilgi okuryazarlığı, bilgi ve iletişim teknolojileri okuryazarlığı, medya okuryazarlığı; yaşam ve kariyer becerileri başlığı altında esneklik ve uyum, girişimcilik, öz-yönlendirme, sosyal ve kültürler arası etkileşim, üretkenlik, hesap verebilirlik, liderlik ve sorumluluk alma becerileridir. Türkçe Dersi Öğretim Programı'nı 21. yüzyıl becerileri açısından analiz edebilmek için bir belirtke tablosu hazırlanmıştır. Belirtke tablosu 19 satır ve 7 sütundan oluşmaktadır. Satırlarda 21. yüzyıl becerilerine, sütunlarda ise yetkinlik, özel amaç, kazanımlar, tema ve konu önerileri, öğrenme-öğretme süreçleri, ölçme ve değerlendirmeye yer verilmiştir. 


\section{Verilerin Analizi}

Türkçe Dersi Öğretim Programı, betimsel analiz kullanılarak incelenmiştir. Türkçe Dersi Öğretim Programı́nda yer alan 21. yüzyıl becerilerini incelemek için doküman analizinin aşamaları takip edilmiştir. Doküman analizi sürecinde dokümanlara ulaşma, orijinalliği (özgünlüğü) kontrol etme, dokümanları anlama, veriyi analiz etme ve veriyi kullanma aşamaları izlenmiştir (Yıldırım ve Şimşek, 2018). Bu aşamalara uygun olarak araştırmada 21. yüzyıl becerilerini ifade eden kategori ve kodlar belirlenmiştir. Kelime, cümle veya paragraf gibi kendi içinde anlamlı olan bölümler isimlendirilerek kodlanmıştır (Yıldırım ve Şimşek, 2018). Doküman incelenirken bu kategori ve kodlar çerçevesinde notlar alınarak bulgular yorumlanmış ve sayısallaştırılarak sunulmuştur. Kodların güvenilirliğini sağlamak amacıyla Türkçe Öğretim Programı, üç uzman (iki eğitim programları ve öğretim ile bir Türkçe eğitimi alan uzmanı) tarafından ayrı ayrı kodlanmış ve Miles ve Huberman'ın (1994) formülü kullanılarak güvenilirlik katsayısı 0.91 olarak hesaplanmıştır.

\section{Bulgular}

Ortaokul Türkçe Dersi Öğretim Programı́nın amaçlarında (kazanım, yetkinlik, özel amaç), içerik, öğrenme-öğretme süreçleri ve değerlendirme ögelerinde 21. yüzyıl becerilerine yer verilme durumuna ilişkin bulgular sunulmuştur.

1. Türkçe Dersi Öğretim Programı'nın Amaçlarında (Kazanım, Yetkinlik, Özel Amaç) 21. Yüzyıl Becerilerine Yer Verilme Durumu Nedir?

21. yüzyıl becerileri açısından analiz edilmeden önce Ortaokul Türkçe Dersi Öğretim Programı'nın kazanımları incelenmiştir. Buna göre Ortaokul Türkçe Dersi Öğretim Programı'nda 5. Sınıflar için 69, 6. sınıf için 68, 7.ve 8. sınıflar için 76 kazanım bulunmaktadır (MEB, 2018, s. 20). Tablo 1'de Ortaokul Türkçe Dersi Öğretim Programı́nın yetkinlik, amaç ve kazanımlarında 21. yüzyıl becerilerine yer verilme durumu gösterilmiştir. Kazanım sayıları fazla olduğu için tamamına değil, örnek kazanımlara yer verilmiştir. Tablo 2'de ise sınıf düzeylerine göre programın kazanımlarında 21. yüzyıl becerilerine yer verilme yüzdeleri sunulmuştur.

Tablo 1. Ortaokul Türkçe Dersi Öğretim Programı'nın Yetkinlik, Amaç ve Kazanımlarında 21. Yüzyıl Becerilerine Yer Verilme Durumu

\begin{tabular}{|c|c|c|}
\hline $\begin{array}{l}\text { 21. Yüzyıl } \\
\text { Becerileri }\end{array}$ & $\begin{array}{l}\text { Yetkinlik, Amaç } \\
\text { ve Kazanım } \\
\text { Sayısı }\end{array}$ & Yetkinlik, Amaç ve Kazanımlar \\
\hline Problem & 2 Yetkinlik & Yetkinlik: \\
\hline Çözme & 34 Kazanım & $\begin{array}{l}\text { Matematiksel yetkinlik: “Günlük hayatta karşılaşılan bir dizi problemi çözmek } \\
\text { için matematiksel düşünme tarzını geliştirme ve uygulamadır." } \\
\text { Sosyal ve vatandaşlıkla ilgili yetkinlikler: "Bu yetkinlikler kişisel, kişiler arası } \\
\text { ve kültürler arası yetkinlikleri içermekte; bireylerin farklılaşan toplum ve } \\
\text { çalışma hayatına etkili ve yapıcı biçimde katılmalarına imkân tanıyacak; } \\
\text { gerektiğinde çatışmaları çözecek özelliklerle donatılmasını sağlayan tüm } \\
\text { davranış biçimlerini kapsar." }\end{array}$ \\
\hline
\end{tabular}




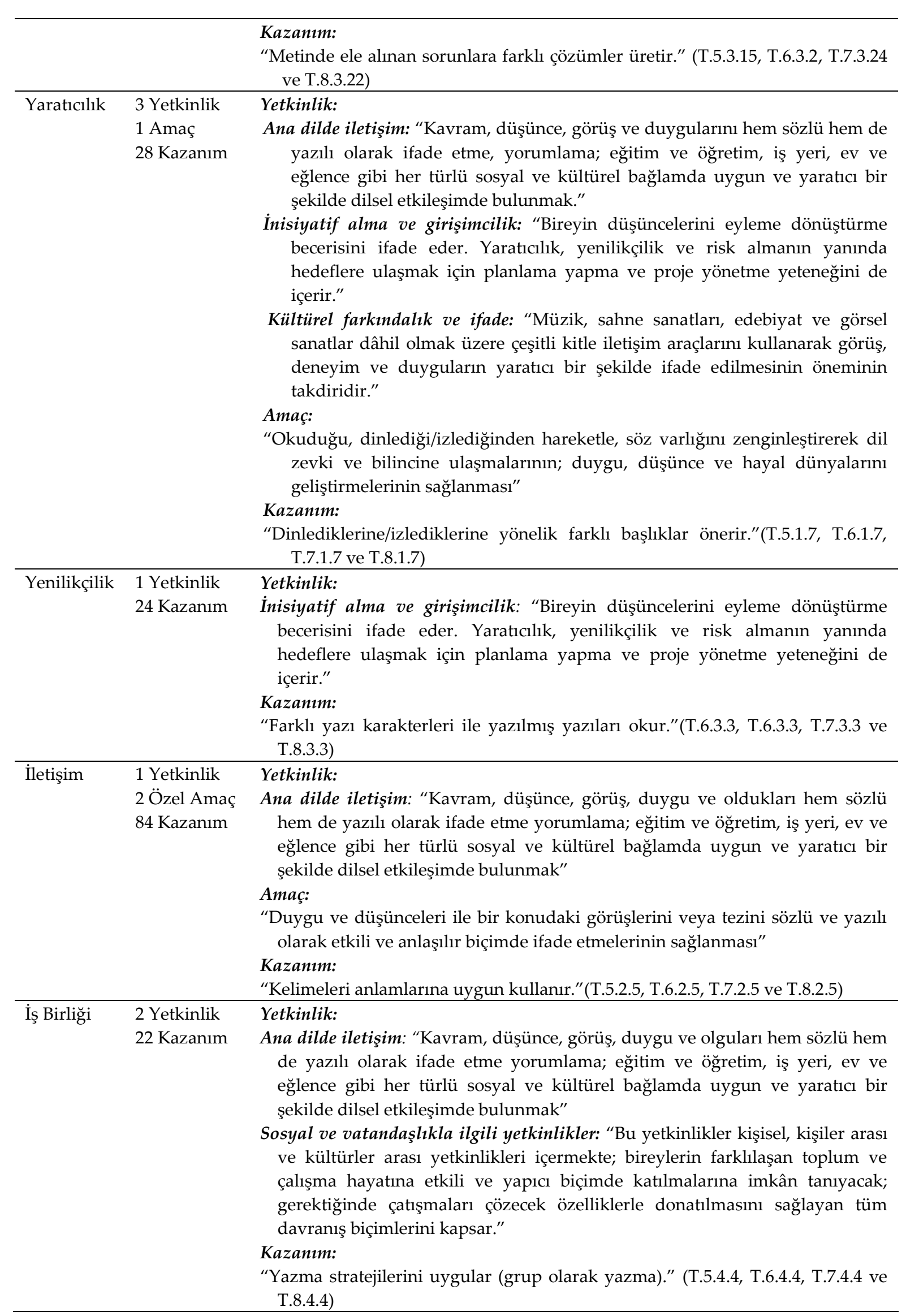




\begin{tabular}{|c|c|c|}
\hline Eleştirel & 1 Yetkinlik & Yetkinlik: \\
\hline Düşünme & $\begin{array}{l}1 \text { Özel Amaç } \\
75 \text { Kazanım }\end{array}$ & $\begin{array}{l}\text { Dijital yetkinlik: “İş, günlük hayat ve iletişim için bilgi ve iletişim } \\
\text { teknolojilerini güvenli ve eleştirel bir şekilde kullanılmasını kapsar." } \\
\text { Amaç: } \\
\text { "Okuduklarını anlayarak eleştirel bir bakış açısıyla } \\
\text { değerlendirmelerinin ve sorgulamalarının sağlanması" } \\
\text { Kazanım: } \\
\text { "Okudukları ile ilgili çıkarımlarda bulunur."(T.5.3.31, T.6.3.29, T.7.3.28 } \\
\text { ve T.8.3.25) }\end{array}$ \\
\hline Karar Verme & 86 Kazanım & $\begin{array}{l}\text { Kazanım: } \\
\text { "Medya metinlerini analiz eder."(T.8.3.29, T.7.3.17 ve T.8.3.17) }\end{array}$ \\
\hline $\begin{array}{l}\text { Öğrenmeyi } \\
\text { Öğrenme }\end{array}$ & $\begin{array}{l}1 \text { Yetkinlik } \\
2 \text { Özel Amaç } \\
40 \text { Kazanım }\end{array}$ & $\begin{array}{l}\text { Yetkinlik: } \\
\text { Ö̆̆renmeyi öğrenme: “Bireyin kendi öğrenme eylemini etkili zaman ve } \\
\text { bilgi yönetimini de kapsayacak şekilde kullanmasını kapsar." } \\
\text { Amaç: } \\
\text { "Bilgiyi araştırma, keşfetme, yorumlama ve zihinde yapılandırma } \\
\text { becerilerinin geliştirilmesi" } \\
\text { "Okuduğu, dinlediği/izlediğinden hareketle söz varlığını } \\
\text { zenginleştirerek dil zevki ve bilincine ulaşmalarının; duygu, düşünce } \\
\text { ve hayal dünyalarını geliştirmelerinin sağlanması" } \\
\text { Kazanım: } \\
\text { "Metinle ilgili sorular sorar." (T.5.3.18, T.6.3.18, T.8.3.15 ve T.8.3.15) }\end{array}$ \\
\hline Bilgi & 1 Yetkinlik & Yetkinlik: \\
\hline Okuryazarlığı & $\begin{array}{l}2 \text { Özel Amaç } \\
26 \text { kazanım }\end{array}$ & $\begin{array}{l}\text { Bilim/teknolojide temel yetkinlikler: “Bilimde yetkinlik, soruları } \\
\text { tanımlamak ve kanıta dayalı sonuçlar üretmek amacıyla doğal } \\
\text { dünyanın açıklanmasına yönelik bilgi varlığına ve metodolojiden } \\
\text { yararlanma beceri ve arzusuna atıfta bulunmaktadır." }\end{array}$ \\
\hline
\end{tabular}

Amaç:

"Bilgiyi araştırma, keşfetme, yorumlama ve zihinde yapılandırma becerilerinin geliştirilmesi"

“Okuma yazma sevgisi ve alışkanlığını kazanmalarının sağlanması”

Kazanim:

"Grafik, tablo ve çizelgeyle sunulan bilgilere ilişkin soruları cevaplar." (T.5.3.34, T.6.3.35, T.7.3.34 ve T.8.3.32)

\begin{tabular}{ll}
\hline Bilgi ve & 2 Yetkinlik \\
İletişim & 1 Özel Amaç \\
Teknolojileri & 30 Kazanım \\
Okuryazarlığı &
\end{tabular}

Yetkinlik:

Dijital yetkinlik: “İş, günlük hayat ve iletişim için bilgi ve iletişim teknolojilerini güvenli ve eleştirel bir şekilde kullanılmasını kapsar."

Bilim/teknolojide temel yetkinlikler: “Bilimde yetkinlik, soruları tanımlamak ve kanıta dayalı sonuçlar üretmek amacıyla doğal dünyanın açıklanmasına yönelik bilgi varlığına ve metodolojiden yararlanma beceri ve arzusuna atıfta bulunmaktadır. Teknolojide yetkinlik, algılanan insan istek ve ihtiyaçlarını karşılama bağlamında bilgi ve metodolojinin uygulanması olarak görülmektedir. Bilim ve teknolojide yetkinlik, insan etkinliklerinden kaynaklanan değişimleri ve her bireyin vatandaş olarak sorumluluklarını kavrama gücünü kapsamaktadır."

Amaç:

"Basılı materyaller ile çoklu medya kaynaklarından bilgiye erişme, bilgiyi düzenleme, sorgulama, kullanma ve üretme becerilerinin geliştirilmesi"

Kazanım:

“Bilgi kaynaklarının güvenilirliğini sorgular.” (T.5.3.29, T.6.3.34, T.7.3.33 ve T.8.3.31) 


\begin{tabular}{|c|c|c|}
\hline Medya & 1 Yetkinlik & Yetkinlik: \\
\hline Okuryazarlığı & $\begin{array}{l}1 \text { Özel Amaç } \\
24 \text { Kazanım }\end{array}$ & $\begin{array}{l}\text { Dijital yetkinlik: "İş, günlük hayat ve iletişim için bilgi ve iletişim } \\
\text { teknolojilerini güvenli ve eleştirel bir şekilde kullanılmasını kapsar." } \\
\text { Amaç: } \\
\text { "Basılı materyaller ile çoklu medya kaynaklarından bilgiye erişme, } \\
\text { bilgiyi düzenleme, sorgulama, kullanma ve üretme becerilerinin } \\
\text { geliştirilmesi" } \\
\text { Kazanım: } \\
\text { "Dinlediklerinde/izlediklerinde tutarlılığı sorgular." (T.7.1.10 ve T.8.1.9) }\end{array}$ \\
\hline $\begin{array}{l}\text { Esneklik ve } \\
\text { Uyum }\end{array}$ & 32 Kazanım & $\begin{array}{l}\text { Kazanım: } \\
\text { "Bağlamdan yararlanarak bilmediği kelime ve kelime gruplarının } \\
\text { anlamını tahmin eder." (T.5.3.5, T.6.3.5, T.7.3.5 ve T.8.3.5) }\end{array}$ \\
\hline Girişimcilik & $\begin{array}{l}1 \text { Yetkinlik } \\
28 \text { Kazanım }\end{array}$ & $\begin{array}{l}\text { Yetkinlik: } \\
\text { Inisiyatif alma ve girişimcilik: "Bireyin düşüncelerini eyleme } \\
\quad \text { dönüştürme becerisini ifade eder. Yaratıcılık, yenilikçilik ve risk } \\
\text { almanın yanında hedeflere ulaşmak için planlama yapma ve proje } \\
\text { yönetme yeteneğini de içerir." } \\
\text { Kazanım: } \\
\text { "Hazırlıksız konuşma yapar." (T.5.2.2, T.6.2.2, T.7.2.2 ve T.8.2.2) }\end{array}$ \\
\hline $\begin{array}{l}\text { Öz- } \\
\text { yönlendirme }\end{array}$ & 34 Kazanım & $\begin{array}{l}\text { Kazanım: } \\
\text { "Yazdıklarını düzenler."(T.5.4.9, T.6.4.10, T.7.4.16 ve T.8.4.16) }\end{array}$ \\
\hline $\begin{array}{l}\text { Sosyal ve } \\
\text { Kültürler } \\
\text { Arası } \\
\text { Etkileşim }\end{array}$ & $\begin{array}{l}2 \text { Yetkinlik } \\
2 \text { Özel Amaç } \\
34 \text { Kazanım }\end{array}$ & $\begin{array}{l}\text { Yetkinlik: } \\
\text { Kültürel farkındalık ve ifade: “Müzik, sahne sanatları, edebiyat ve } \\
\text { görsel sanatlar dâhil olmak üzere çeşitli kitle iletişim araçlarını } \\
\text { kullanarak görüş, deneyim ve duyguların yaratıcı bir şekilde ifade } \\
\text { edilmesinin öneminin takdiridir." } \\
\text { Sosyal ve vatandaşlıkla ilgili yetkinlikler: "Bu yetkinlikler kişisel, } \\
\text { kişiler arası ve kültürler arası yetkinlikleri içermekte; bireylerin } \\
\text { farklılaşan toplum ve çalışma hayatına etkili ve yapıcı biçimde } \\
\text { katılmalarına imkân tanıacak, gerektiğinde çatışmaları çözecek } \\
\text { özelliklerle donatılmasını sağlayan tüm davranış biçimlerini kapsar.” } \\
\text { Amaç: } \\
\text { “Türk ve dünya kültür ve sanatına ait eserler aracılığılyla estetik ve } \\
\text { sanatsal değerleri fark etmelerinin ve benimsemelerinin sağlanması } \\
\text { amaçlanmıştır.” } \\
\text { “Millî, manevi, ahlaki, tarihî, kültürel, sosyal değerlere önem } \\
\text { vermelerinin sağlanması, millî duygu ve düşüncelerinin } \\
\text { güçlendirilmesi” } \\
\text { Kazanım: } \\
\text { “Yazılarını zenginleştirmek için atasözleri, deyimler ve özdeyişler } \\
\text { kullanır." (T.5.4.7, T.6.4.7, T.7.4.7 ve T.8.4.7) }\end{array}$ \\
\hline Üretkenlik & $\begin{array}{l}1 \text { Yetkinlik } \\
75 \text { Kazanım }\end{array}$ & $\begin{array}{l}\text { Yetkinlik: } \\
\text { Bilimde yetkinlik: "Soruları tanımlamak ve kanıta dayalı sonuçlar } \\
\text { üretmek amacıyla doğal dünyanın açıklanmasına yönelik bilgi } \\
\text { varlığına ve metodolojiden yararlanma beceri ve arzusuna atıfta } \\
\text { bulunmaktadır." } \\
\text { Kazanım: } \\
\text { "Şiir yazar." (T.5.4.1, T.6.4.1, T.7.4.1 ve T.8.4.1) }\end{array}$ \\
\hline $\begin{array}{l}\text { Hesap } \\
\text { Verebilirlik }\end{array}$ & $\begin{array}{l}1 \text { Özel Amaç } \\
52 \text { Kazanım }\end{array}$ & $\begin{array}{l}\text { Amaç: } \\
\text { "Duygu ve düşünceleri ile bir konudaki görüşlerini veya tezini sözlü ve } \\
\text { yazılı olarak etkili ve anlaşılır biçimde ifade etmelerinin sağlanması" } \\
\text { Kazanım: } \\
\text { "Yazdıklarını desteklemek için gerektiğinde grafik ve tablo kullanır." } \\
\text { (T.6.4.5.) }\end{array}$ \\
\hline
\end{tabular}




\begin{tabular}{lll}
\hline Liderlik ve & 1 Yetkinlik & Yetkinlik: \\
Sorumluluk & 28 Kazanım & $\begin{array}{l}\text { Ínisiyatif alma ve girişimcilik: "Bireyin düşüncelerini eyleme } \\
\text { dönüştürme becerisini ifade eder. Yaratıcıllk, yenilikçilik ve risk } \\
\text { Alma }\end{array}$ \\
$\begin{array}{l}\text { almanın yanında hedeflere ulaşmak için planlama yapma ve proje } \\
\text { yönetme yeteneğini de içerir." }\end{array}$
\end{tabular}

Kazanım:

“Yazdıklarını paylaşır.” (T.5.4.10, T.6.4.11, T.7.4.17 ve T.8.4.17)

Tablo 2. Ortaokul Türkçe Dersi Öğretim Programı'nın Yetkinlik, Amaç ve Kazanımlarında 21. Yüzyıl Becerilerinin Sınıflara Göre Dağılımı

\begin{tabular}{|c|c|c|c|c|c|c|c|c|}
\hline \multirow{2}{*}{ 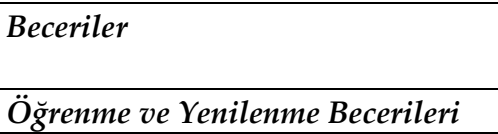 } & \multicolumn{2}{|c|}{ 5.Sinif } & \multicolumn{2}{|c|}{ 6.Stnıf } & \multicolumn{2}{|c|}{ 7. Sinif } & \multicolumn{2}{|c|}{ 8. Sinıf } \\
\hline & $\mathbf{N}$ & $\%$ & $\mathbf{N}$ & $\%$ & $\mathbf{N}$ & $\%$ & $\mathbf{N}$ & $\%$ \\
\hline Problem Çözme & 8 & 11,7 & 8 & 11,7 & 9 & 11,8 & 9 & 11,8 \\
\hline Yaratıcilık & 7 & 10,1 & 7 & 10,2 & 7 & 9,2 & 7 & 9,2 \\
\hline Yenilikçilik & 6 & 8,7 & 6 & 8,8 & 6 & 7,9 & 6 & 7,9 \\
\hline İletişim & 21 & 30,4 & 21 & 30,8 & 21 & 27,7 & 21 & 27,6 \\
\hline İş birliği & 5 & 7,2 & 5 & 7,3 & 6 & 7,9 & 6 & 7,9 \\
\hline Eleştirel Düşünme & 16 & 23,1 & 16 & 23,5 & 21 & 27,6 & 22 & 28,9 \\
\hline Karar Verme & 20 & 29,4 & 19 & 29 & 24 & 31,5 & 23 & 30,2 \\
\hline Öğrenmeyi öğrenme & 10 & 14,5 & 10 & 14,7 & 10 & 13,1 & 10 & 13,1 \\
\hline \multicolumn{9}{|l|}{ Bilgi, Medya ve Teknoloji Becerileri } \\
\hline Bilgi Okuryazarlığ & 6 & 8,7 & 6 & 8,8 & 7 & 9,2 & 8 & 10,5 \\
\hline $\begin{array}{l}\text { Bilgi ve İletişim Teknolojileri } \\
\text { Okuryazarlığı }\end{array}$ & 7 & 10,1 & 7 & 10,2 & 8 & 10,5 & 8 & 10,5 \\
\hline Medya Okuryazarlığ1 & 5 & 7,2 & 5 & 7,3 & 7 & 9,2 & 7 & 9,2 \\
\hline \multicolumn{9}{|l|}{ Yaşam ve Kariyer Becerileri } \\
\hline Esneklik ve Uyum & 8 & 11,6 & 8 & 11,7 & 8 & 10,5 & 8 & 10,5 \\
\hline Girişimcilik & 7 & 10,1 & 7 & 10,3 & 7 & 9,2 & 7 & 9,2 \\
\hline Öz yönlendirme & 8 & 11,6 & 8 & 11,7 & 8 & 10,5 & 8 & 10,5 \\
\hline Sosyal ve Kültürler arası Etkileşim & 8 & 11,6 & 8 & 11,7 & 8 & 10,5 & 10 & 13,1 \\
\hline Üretkenlik & 18 & 26 & 19 & 27 & 19 & 25 & 19 & 25 \\
\hline Hesap verebilirlik & 11 & 16 & 12 & 17,6 & 15 & 20 & 14 & 18,4 \\
\hline Liderlik ve Sorumluluk Alma & 7 & 10,1 & 7 & 10,3 & 7 & 9,2 & 7 & 9,2 \\
\hline
\end{tabular}

Tablo 1 ve 2'ye göre, ortaokul Türkçe Dersi Öğretim Programı'nın amaç ve kazanımlarında 21. yüzyıl becerilerinin tamamına yer verildiği, özellikle öğrenme ve yenilenme becerilerinden iletişim, karar verme, eleştirel düşünme; yaşam ve kariyer becerilerinden üretkenlik becerilerini yansıtan amaç ve kazanımların programda oldukça fazla olduğu görülmüştür. Türkçe Dersi Öğretim Programı'nın amaç ve kazanımlarında 1 yetkinlik (ana dilde iletişim), 2 özel amaç ve toplamda 84 kazanım ile en çok ilişkilendirilen beceri ise iletişim becerisidir. Her sınıf düzeyi için 21 kazanım, başka bir deyişle kazanımların yaklaşık üçte biri iletişim becerisine yöneliktir. Ortaokul Türkçe Dersi Öğretim Programı'nın amaç ve kazanımları incelendiğinde karar verme becerisi ile ilişkilendirilen 86 kazanım tespit edilmiştir. 5. ve 6. sınıflarda kazanımların dörtte birinden fazlasının, yine 7. ve 8. sınıflarda kazanımların üçte birine yakınının karar verme becerisi ile ilişkili olması dikkat çekicidir. Karar verme becerisine 7. ve 8. sınıf kazanımlarında daha fazla yer verildiği anlaşılmaktadır. Eleştirel düşünme becerisi ile ilişkilendirilen 1 yetkinlik (dijital yetkinlik), 1 amaç ve 76 kazanıma rastlanmıştır. Tüm sınıf 
düzeylerinde kazanımların yaklaşık dörtte birinde eleştirel düşünme becerisine yer verildiği görülmektedir. Programda en çok yer verilen becerilerden biri de üretkenliktir. Üretkenlik becerisiyle ilişkili 1 yetkinlik (bilimde yetkinlik) ve 75 kazanım vardır. Kazanımların yaklaşık dörtte birinin üretkenlik becerisiyle ilişkili olduğu söylenebilir. Türkçe dersi sözlü ve yazılı iletişime dayalı olduğu için program kazanımlarında en fazla iletişim becerisine yer verilmesi, olması gereken bir durum olarak değerlendirilmiştir. Türkçe Dersi Öğretim Programı'nın temelini oluşturan metin analizleri, kendini ifade etme, okuduğunu/dinlediğini anlama ve yorumlama, yazma/konuşma stratejileri uygulama gibi etkinliklerin tamamı karar verme, eleştirel düşünme ve üretkenlik becerilerinin kullanımını gerektirmektedir.

Programda yenilikçilik, iş birliğii, medya okuryazarlığı, bilgi okuryazarlığı, girişimcilik gibi becerileri yansıtan kazanım sayısının diğerlerine göre daha az olduğu belirlenmiştir. Türkçe Dersi Öğretim Programı'nın amaç ve kazanımlarında yenilikçilik becerisiyle ilişkilendirilen 1 yetkinlik (inisiyatif alma ve girişimcilik) ve 24 kazanım; medya okuryazarlı̆̆ı becerisi ile ilişkilendirilen 1 yetkinlik (dijital yetkinlik), 1 amaç ve 24 kazanım; bilgi okuryazarlı̆̆ı becerisi ile ilişkilendiren 1 yetkinlik (bilim/teknolojide temel yetkinlikler), 2 amaç ve 26 kazanım; girişimcilik ve liderlik ve sorumluluk alma becerisiyle ilişkilendirilen 1 yetkinlik (inisiyatif alma ve girişimcilik) ve 28 kazanım; iş birliği becerisi ile ilişkilendirilen 2 yetkinlik (ana dilde iletişim, sosyal ve vatandaşlıkla ilgili yetkinlikler) ve 22 kazanım olduğu tespit edilmiştir. Türkçe Dersi Öğretim Programı'nda en az yer verilen beceriler bilgi, medya ve teknolojileri ile yaşam ve kariyer becerileri olarak belirlenmiştir. Oysa günümüzde neredeyse tüm öğretim programlarında bilgi ve medya teknolojileri becerilerinin yer alması gerekmektedir. Özellikle de yüz yüze eğitime geçilse bile hibrid eğitimin (yüz yüze ve online) bundan sonra da devam edeceği düşünüldüğünde tüm öğrencilerin ve öğretmenlerin bu becerilere sahip olmaları daha da önem kazanmıştır.

\section{Türkçe Dersi Öğretim Programı'nın İçeriğinde 21. Yüzyıl Becerilerine Yer Verilme Durumu}

\section{Nedir?}

Kazanımlardan sonra ortaokul Türkçe Dersi Öğretim Programı'nın tema ve konu başlıklarında 21. yüzyıl becerilerine yer verilme durumu incelenmiştir. Ortaokul Türkçe Dersi Öğretim Programı'nın uygulanması sürecinde her sınıf düzeyinde 8 tema işlenmesi öngörülmüştür. “Erdemler", "Millî Kültürümüz", "Millî Mücadele ve Atatürk” temalarının her sınıf düzeyinde işlenmesi zorunludur. Zorunlu temalar dişında verilen diğer temalar (Birey ve Toplum, Okuma Kültürü, İletişim, Hak ve Özgürlükler, Kişisel Gelişim, Bilim ve Teknoloji, Sağlık ve Spor, Zaman ve Mekân, Duygular, Doğa ve Evren, Sanat, Vatandaşlık, Çocuk Dünyası temaları) seçmeli olup kitap yazarlarınca belirlenebilmektedir (MEB, 2018, s. 16). Tablo 3'te Türkçe Dersi Öğretim Programı'nın içeriğinde 21. yüzyıl becerilerine yer verilme durumu gösterilmektedir. Türkçe Dersi Öğretim 
Programı'nda temalar ve konu önerileri sınıf ayrımı yapılmadan verildiği için tabloda da sınıf ayrımı yapılmadan gösterilmiştir.

Tablo 3. Ortaokul Türkçe Dersi Öğretim Programı'nın İçeriğinde 21. Yüzyıl Becerilerine Yer Verilme Durumu

\begin{tabular}{|c|c|c|c|}
\hline Beceriler & $\begin{array}{l}\text { Tema ve } \\
\text { Konu } \\
\text { Sayısı }\end{array}$ & Tema & Konu \\
\hline \multirow[t]{6}{*}{$\begin{array}{l}\text { Problem } \\
\text { Çözme }\end{array}$} & \multirow[t]{6}{*}{$\begin{array}{l}6 \text { tema } \\
15 \text { konu }\end{array}$} & $\begin{array}{l}\text { Millî Mücadele ve } \\
\text { Atatürk }\end{array}$ & $\begin{array}{l}\text { "15 Temmuz, Çanakkale, Atatürk, Millî mücadele, } \\
\text { Kut'ül-Amare, millî irade" }\end{array}$ \\
\hline & & Birey ve Toplum & "Hayat becerileri, zaman yönetimi" \\
\hline & & Kişisel Gelişim & "Karar verme, meslek seçimi" \\
\hline & & Bilim ve Teknoloji & $\begin{array}{l}\text { "Bilim insanları, keşif ve icatlar, matematik } \\
\text { okuryazarlığı" }\end{array}$ \\
\hline & & Duygular & "Duygu yönetimi" \\
\hline & & Sağlık ve Spor & "İlk yardım" \\
\hline \multirow[t]{4}{*}{ Yaratıcilık } & \multirow[t]{4}{*}{$\begin{array}{l}4 \text { tema } \\
14 \text { konu }\end{array}$} & Bilim ve Teknoloji & $\begin{array}{l}\text { "Merak duygusu, patent, tasarım, keşif ve icatlar, bilim } \\
\text { insanları, hayal gücü" }\end{array}$ \\
\hline & & Sanat & "Özgünlük, estetik, heykel, mimari, resim, seramik" \\
\hline & & Okuma Kültürü & "Yaratıcı okuma" \\
\hline & & Kişisel Gelişim & "Yetenek, yeterlilik" \\
\hline \multirow[t]{3}{*}{ Yenilikçilik } & \multirow{3}{*}{$\begin{array}{l}3 \text { tema } \\
8 \text { konu }\end{array}$} & Bilim ve Teknoloji & "Yenilikçilik, keşif ve icatlar, merak duygusu, teknoloji" \\
\hline & & Sanat & "Yenilikçi düşünme, özgünlük" \\
\hline & & Çocuk Dünyası & "Keşif, hayal" \\
\hline \multirow[t]{5}{*}{ İletişim } & \multirow[t]{5}{*}{$\begin{array}{l}5 \text { tema } \\
21 \text { konu }\end{array}$} & İletişim & $\begin{array}{l}\text { "Aile iletişimi, bilgi iletişimi, diğer canlılarla iletişim, } \\
\text { etkili iletişim, iletişim becerileri, insanlarla iletişim, kitle } \\
\text { iletişim araçları, komşuluk, kültürel iletişim, kültürler } \\
\text { arası iletişim, medya okuryazarlığı, öğrenci hareketliliği, } \\
\text { öğrenci öğretmen iletişimi" }\end{array}$ \\
\hline & & Bilim ve Teknoloji & "Haberleşme, iletişim, sosyal medya" \\
\hline & & Kişisel Gelişim & "Sosyal gelişim, empati" \\
\hline & & Duygular & "Bağışlama" \\
\hline & & Çocuk Dünyası & "Geleneksel çocuk oyunları, sokak oyunları" \\
\hline \multirow[t]{5}{*}{ İş Birliği } & \multirow[t]{5}{*}{$\begin{array}{l}5 \text { tema } \\
17 \text { konu }\end{array}$} & Birey ve Toplum & $\begin{array}{l}\text { "Dayanışma, hayat becerileri, kardeşlik, komşuluk } \\
\text { ilişkileri, sosyokültürel farkındalık" }\end{array}$ \\
\hline & & Vatandaşlik & "Mültecilik, iş birliği, paylaşma" \\
\hline & & Erdemler & $\begin{array}{l}\text { "Paylaşma, kardeşlik, dayanışma, dostluk, iyilikseverlik, } \\
\text { yardımlaşma" }\end{array}$ \\
\hline & & Millî kültürümüz & "Vakıf kültürü" \\
\hline & & Çocuk Dünyası & "Geleneksel çocuk oyunları, sokak oyunları" \\
\hline \multirow{3}{*}{$\begin{array}{l}\text { Eleştirel } \\
\text { Düşünme }\end{array}$} & \multirow{3}{*}{$\begin{array}{l}3 \text { tema } \\
3 \text { konu }\end{array}$} & Okuma Kültürü & "Eleştirel okuryazarlık" \\
\hline & & Kişisel Gelişim & “Öz eleştiri" \\
\hline & & $\begin{array}{l}\text { Hak ve } \\
\text { Özgürlükler }\end{array}$ & “Düşünce özgürlüğü" \\
\hline \multirow[t]{3}{*}{ Karar Verme } & \multirow{3}{*}{$\begin{array}{l}3 \text { tema } \\
6 \text { konu }\end{array}$} & Kişisel Gelişim & "Karar verme, meslek seçimi, çatışma yönetimi" \\
\hline & & $\begin{array}{l}\text { Millî Mücadele ve } \\
\text { Atatürk }\end{array}$ & “Cesaret, millî irade" \\
\hline & & Okuma Kültürü & "Eleştirel okuryazarlık" \\
\hline \multirow{3}{*}{$\begin{array}{l}\text { Öğrenmeyi } \\
\text { Öğrenme }\end{array}$} & \multirow{3}{*}{$\begin{array}{l}3 \text { tema } \\
8 \text { konu }\end{array}$} & Kişisel Gelişim & "Öğrenmeyi öğrenme, motivasyon" \\
\hline & & Okuma Kültürü & $\begin{array}{l}\text { "Bilgi okuryazarlığı, dijital okuryazarlık, kütüphaneler, } \\
\text { okuma alışkanlığı, okuma sevgisi" }\end{array}$ \\
\hline & & Bilim ve Teknoloji & "Merak duygusu" \\
\hline
\end{tabular}




\begin{tabular}{|c|c|c|c|}
\hline \multirow[t]{2}{*}{$\begin{array}{l}\text { Bilgi } \\
\text { Okuryazarlığ1 }\end{array}$} & \multirow[t]{2}{*}{$\begin{array}{l}2 \text { tema } \\
12 \text { konu }\end{array}$} & \multirow[t]{2}{*}{$\begin{array}{l}\text { Okuma Kültürü } \\
\text { Bilim ve Teknoloji }\end{array}$} & \multirow[t]{2}{*}{$\begin{array}{l}\text { "Bilgi okuryazarlığı, çoklu okuryazarlık, dijital } \\
\text { okuryazarlık, teknoloji okuryazarlığı, e-kitap, okur } \\
\text { kimliği, sözlük kültürü, okuma alışkanlığ1, okuma } \\
\text { serüveni, okuma sevgisi" } \\
\text { "Bilim insanları, bilim okuryazarlığı" }\end{array}$} \\
\hline & & & \\
\hline \multirow{3}{*}{$\begin{array}{l}\text { Bilgi ve } \\
\text { İletişim } \\
\text { Teknolojileri } \\
\text { Okuryazarlığ1 }\end{array}$} & \multirow[t]{3}{*}{$\begin{array}{l}3 \text { tema } \\
13 \text { konu }\end{array}$} & Bilim ve Teknoloji & $\begin{array}{l}\text { "Bilim insanları, bilim okuryazarlığı, bilişim } \\
\text { okuryazarlığı, iletişim, keşif ve icatlar, patent, sosyal } \\
\text { medya, tasarım, teknoloji, ulaşım" }\end{array}$ \\
\hline & & Çocuk Dünyası & "Dijital oyunlar" \\
\hline & & İletişim & "Bilgi iletişimi, kitle iletişim araçları" \\
\hline \multirow{2}{*}{$\begin{array}{l}\text { Medya } \\
\text { Okuryazarlığ1 }\end{array}$} & \multirow{2}{*}{$\begin{array}{l}2 \text { tema } \\
5 \text { konu }\end{array}$} & İletişim & "Medya okuryazarlığı, kitle iletişim araçları" \\
\hline & & Bilim ve Teknoloji & "Haberleşme, iletişim, sosyal medya" \\
\hline \multirow{3}{*}{$\begin{array}{l}\text { Esneklik Ve } \\
\text { Uyum }\end{array}$} & \multirow{3}{*}{$\begin{array}{l}3 \text { tema } \\
8 \text { konu }\end{array}$} & Kişisel Gelişim & "Çatışma yönetimi, kendini tanıma, olumlu düşünme" \\
\hline & & Duygular & "Duygu yönetimi" \\
\hline & & Birey ve Toplum & $\begin{array}{l}\text { "Çok kültürlülük, farklılıklara saygı, küreselleşme, } \\
\text { zaman yönetimi" }\end{array}$ \\
\hline \multirow[t]{4}{*}{ Girişimcilik } & \multirow{4}{*}{$\begin{array}{l}4 \text { tema } \\
8 \text { konu }\end{array}$} & Kişisel Gelişim & "Girişimcilik, öz güven, başarı, beceri, çalışkanlık" \\
\hline & & Bilim ve Teknoloji & "Girişimcilik" \\
\hline & & $\begin{array}{l}\text { Millî Mücadele ve } \\
\text { Atatürk }\end{array}$ & "Cesaret" \\
\hline & & Birey ve Toplum & "Meslekler" \\
\hline \multirow[t]{2}{*}{$\begin{array}{l}\text { Öz- } \\
\text { Yönlendirme }\end{array}$} & \multirow[t]{2}{*}{$\begin{array}{l}2 \text { tema } \\
9 \text { konu }\end{array}$} & Kişisel Gelişim & $\begin{array}{l}\text { "Öz denetim, öz eleştiri, zaman yönetimi, kendini } \\
\text { tanıma, kişilik tipleri, meslek seçimi, öz güven, öz saygı" }\end{array}$ \\
\hline & & Duygular & "Duygu yönetimi" \\
\hline \multirow[t]{3}{*}{$\begin{array}{l}\text { Sosyal ve } \\
\text { Kültürler } \\
\text { Arası } \\
\text { Etkileşim }\end{array}$} & \multirow[t]{3}{*}{$\begin{array}{l}3 \text { tema } \\
34 \text { konu }\end{array}$} & Millî Kültürümüz & $\begin{array}{l}\text { "Aile, bayrak, büyüklerimiz, dinî bayramlar, gelenekler, } \\
\text { geleneksel sporlar, insan ilişkileri, kültürel miras, } \\
\text { mekânlar, millî bayramlar, şehirlerimiz, tarihî mekânlar, } \\
\text { tarihî şahsiyetler, tarihî eserlerimiz, Türkçe, vakıf } \\
\text { kültürü" }\end{array}$ \\
\hline & & Vatandaşlık & “Mültecilik, paylaşma, göçmenlik, göç” \\
\hline & & Birey ve Toplum & $\begin{array}{l}\text { "Adalet, barış, dayanışma, çok kültürlülük, komşuluk } \\
\text { ilişkileri, kültürel farklılıklar, küreselleşme, medeniyet, } \\
\text { misafirperverlik, selamlaşma, sosyokültürel farkındalık, } \\
\text { toplumsal kurallar, vatandaşlık" }\end{array}$ \\
\hline \multirow[t]{5}{*}{ Üretkenlik } & \multirow{5}{*}{$\begin{array}{l}5 \text { tema } \\
14 \text { konu }\end{array}$} & Bilim ve Teknoloji & "Hayal gücü, tasarım, patent, telif, yenilikçilik" \\
\hline & & Vatandaşlık & "Üretme" \\
\hline & & Çocuk Dünyası & "Hayal, hobiler, keşif, merak" \\
\hline & & Kişisel Gelişim & "Çalışkanlık". \\
\hline & & Okuma Kültürü & "Yazılı kültür, kitaplar, kitabevi" \\
\hline \multirow{4}{*}{$\begin{array}{l}\text { Hesap } \\
\text { Verebilirlik }\end{array}$} & \multirow{4}{*}{$\begin{array}{l}4 \text { tema } \\
12 \text { konu }\end{array}$} & Bilim ve Teknoloji & "Etik" \\
\hline & & Kişisel Gelişim & "Öz denetim" \\
\hline & & Vatandaşlık & $\begin{array}{l}\text { "Görev bilinci, hukukun üstünlüğü, sorumluluk, vergi } \\
\text { bilinci" }\end{array}$ \\
\hline & & $\begin{array}{l}\text { Hak ve } \\
\text { Özgürlükler }\end{array}$ & $\begin{array}{l}\text { "Hakkını savunma, toplumsal cinsiyet adaleti, toplumsal } \\
\text { cinsiyet eşitliği, çocuk hakları, insan hakları, demokrasi" }\end{array}$ \\
\hline \multirow{3}{*}{$\begin{array}{l}\text { Liderlik ve } \\
\text { Sorumluluk } \\
\text { Alma }\end{array}$} & \multirow{3}{*}{$\begin{array}{l}3 \text { tema } \\
10 \text { konu }\end{array}$} & Vatandaşlık & "Sorumluluk, görev bilinci, çalışma, alın teri" \\
\hline & & $\begin{array}{l}\text { Hak ve } \\
\text { Özgürlükler }\end{array}$ & "Demokrasi" \\
\hline & & Birey ve Toplum & $\begin{array}{l}\begin{array}{l}\text { "Hukuk, hükûmet, iktidar, meslekler, toplumsal } \\
\text { kurallar" }\end{array} \\
\end{array}$ \\
\hline
\end{tabular}

Tablo 3'e göre Türkçe Dersi Öğretim Programı'nın içeriğinde en çok yer verilen temalardan olan iletişim becerisi ile ilgili 5 tema ve 21 konu; iş birliği becerisi ilgili 5 tema ve 17 konu; problem çözme becerisiyle ile ilgili 5 tema ve 15 konu; yaratıcılık becerisi ile ilgili 4 tema ve 14 konu; sosyal ve 
kültürler arası etkileşim becerisi ile ilgili 3 tema ve 34 olduğu saptanmıştır. Buna göre Türkçe Dersi Öğretim Programı'nın içeriğinde en fazla yer bulan beceriler iletişim, iş birliği ile sosyal ve kültürler arası etkileşim gibi dersin iletişim becerilerine dayalı yapısını yansıtan becerilerdir. Kazanımlarda olduğu gibi Türkçe Dersi Öğretim Programı́nın içeriğinde de en fazla iletişim becerisi ile ilişkilendirme söz konusudur. Programın içerik ögesinde iletişim, aile, bilgi, diğer canlılarla, insanlarla, kitle ile, kültürel, kültürler arası, öğrenci-öğretmen gibi geniş bir yelpazede ele alınmıştır. İş birliği becerisi ile ilgili olarak en çok üzerinde durulan konular dayanışma, paylaşma, kardeşlik, dostluk, yardımlaşma, komşuluk ilişkileri vb. olmuştur. İçerikte problem çözme becerisi ile ilişkilendirilen başıklardan bazıları hayat becerileri, zaman yönetimi, karar verme, bilim insanları, meslek seçimi, keşif ve icatlar, duygu yönetimi iken; yaratıcılık ile ilişkilendirilen konulardan bazıları ise merak duygusu, patent, tasarım, özgünlük, estetik, yaratıcı okuma, yetenek olmuştur. Görüldüğü gibi Türkçe dersi içeriğinin özellikle öğrenme ve yenilik becerilerini geliştirici nitelikte olduğu söylenebilir.

Ortaokul Türkçe Dersi Öğretim Programı içeriğinde en az yer verilen 21. yüzyıl becerileri 3 tema ve 3 konu ile eleştirel düşünme, 3 tema ve 6 konu ile karar verme, 2 tema ve 5 konu ile ve medya okuryazarlığı, 3 tema ve 8 konu ile öğrenmeyi öğrenme, yenilikçilik ve esneklik ve uyum olmuştur. Eleştirel okuryazarlık, öz eleştiri ve düşünce özgürlüğü konuları eleştirel düşünme becerisi; karar verme, meslek seçimi, çatışma yönetimi, eleştirel okuryazarlık konuları karar verme; medya okuryazarlığı, kitle iletişim araçları, haberleşme, iletişim ve sosyal medya konuları medya okuryazarlığı becerilerine yöneliktir. Programın kazanımlarında daha fazla yer bulan eleştirel düşünme becerisinin içerikte fazlaca yer bulamaması ilginçtir. Medya okuryazarlığı becerisinin ise kazanımlarda olduğu gibi içerikte de fazlaca yer bulamadığı görülmektedir.

\section{Türkçe Dersi Öğretim Programı'nın Öğrenme-Öğretme Sürecinde 21. Yüzyıl Becerilerine Yer}

\section{Verilme Durumu Nedir?}

Ortaokul Türkçe Dersi Öğretim Programı'nın öğrenme öğretme yaklaşımı incelenerek maddeler hâline getirilmiştir. MEB, Türkçe Dersi Öğretim Programı'nın öğrenme-öğretme yaklaşımına göre; dört temel dil becerisinin kazandırılmasında tek bir öğrenme öğretme yaklaşımı benimsenemeyeceği, öğrencilerin hazırbulunuşluk, öğrenme stilleri ve ihtiyaçları, sosyokültürel farklılıkları dikkate alınarak farklı öğretim yöntem ve tekniklerinin kullanılması gerektiğini belirtmiştir (MEB, 2018). 21. yüzyıl becerilerine ortaokul Türkçe Dersi Öğretim Programı'nın öğrenmeöğretme süreçlerinde yer verilme durumu Tablo $4^{\prime}$ te gösterilmiştir. Türkçe Dersi Öğretim Programı'nda öğrenme-öğretme süreçleri sınıf ayrımı yapılmadan açıklandığı için tabloda da sınıf ayrımı yapılmamıştır. Tabloda etkinliklerin tamamına değil, seçilmiş örneklerine yer verilmiştir. 
Tablo 4. Ortaokul Türkçe Dersi Öğretim Programı́nın Öğrenme-Öğretme Süreçlerinde 21. Yüzyıl Becerilerine Yer Verilme Durumu

\begin{tabular}{|c|c|c|}
\hline Beceriler & $\begin{array}{l}\text { Yer Verilme } \\
\text { Durumu/Iffade } \\
\text { Sayısı }\end{array}$ & Örnekler \\
\hline Problem Çözme & " bi & $\begin{array}{l}\text { “Öğrenciler verileri toplama, organize etme ve sınıflamada elde ettikleri } \\
\text { bulguları yazma, düzenleme ve sunmada bilgisayar programlarından } \\
\text { yararlanmaları konusunda teşvik edilmelidir." }\end{array}$ \\
\hline Yaratıcilık & 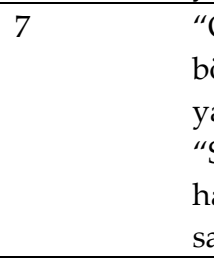 & $\begin{array}{l}\text { “Öğrencilerin konu ve ana fikri belirlemeleri, buna göre giriş, gelişme, sonuç } \\
\text { bölümlerinden oluşan bir metin taslağı oluşturmaları, bu bölümlerde } \\
\text { yazacaklarını belirlemeleri sağlanır.” } \\
\text { “Serbest, güdümlü, yaratıcı, hafızada tutma tekniği ve kelime kavram } \\
\text { havuzundan seçerek konuşma gibi yöntem ve tekniklerin kullanılması } \\
\text { sağlanır.” }\end{array}$ \\
\hline Yenilikçilik & “宅 & $\begin{array}{l}\text { "Öğrenciler yeni öğrendikleri kelimeleri kullanmaya ve günlük hayattan } \\
\text { ornekler vermeye teşvik edilir." }\end{array}$ \\
\hline İletişim & " & $\begin{array}{l}\text { "Not alarak, katılımlı, grup hâlinde dinleme gibi yöntem ve teknikleri } \\
\text { aygulamaları sağlanır." }\end{array}$ \\
\hline İş Birliği & $"$ ". & $\begin{array}{l}\text { “...grup olarak yazma gibi yöntem ve tekniklerin kullanılması sağlanır.” } \\
\text { “...empati kurma, tartışma gibi yöntem ve tekniklerinin kullanılması } \\
\text { sağlanır.” }\end{array}$ \\
\hline $\begin{array}{l}\text { Eleştirel } \\
\text { Düşünme }\end{array}$ & $\begin{array}{l}\text { " } \\
\mathrm{b} \\
\mathrm{y} \\
\text { "c } \\
\mathrm{se}\end{array}$ & $\begin{array}{l}\text { “Öğrenciler verileri toplama, organize etme ve sınıflamada elde ettikleri } \\
\text { bulguları yazma, düzenleme ve sunmada bilgisayar programlarından } \\
\text { yararlanmaları konusunda teşvik edilmelidir.” } \\
\text { “Öğrencilerin dinlediklerindeki / izlediklerindeki tutarlılığı sorgulamaları } \\
\text { sağlanır.” }\end{array}$ \\
\hline Karar Verme & $\begin{array}{l}\text { " } \\
\mathrm{b} \\
\mathrm{y} \\
\mathrm{cl} \\
\mathrm{d} \\
\mathrm{d}\end{array}$ & $\begin{array}{l}\text { “Öğrenciler verileri toplama, organize etme ve sınıflamada elde ettikleri } \\
\text { bulguları yazma, düzenleme ve sunmada bilgisayar programlarından } \\
\text { yararlanmaları konusunda teşvik edilmelidir.” } \\
\text { “Neden-sonuç, amaç-sonuç, koşul, karşılaştırma, benzetme, örneklendirme, } \\
\text { duygu belirten ifadeler, abartma, nesnel ve öznel çıkarımlar üzerinde } \\
\text { durulur.” }\end{array}$ \\
\hline $\begin{array}{l}\text { Öğrenmeyi } \\
\text { Öğrenme }\end{array}$ & 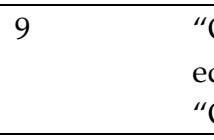 & $\begin{array}{l}\text { “Öğrenciler kendi öğrenmelerinin sorumluluğunu almaları konusunda teşvik } \\
\text { edilmelidir.” } \\
\text { “Öğrenmeye karşı olumlu tutum geliştirmeleri sağlanmalıdır.” }\end{array}$ \\
\hline $\begin{array}{l}\text { Bilgi } \\
\text { Okuryazarlığ } 1\end{array}$ & "1 & $\begin{array}{l}\text { "Bilgi ve iletişim teknolojilerinden yararlanılmalıdır." } \\
\text { “Anlatımı desteklemek için grafik ve tablo kullanmaları sağlanır." }\end{array}$ \\
\hline $\begin{array}{l}\text { Bilgi ve İletişim } \\
\text { Teknolojileri } \\
\text { Okuryazarlığı }\end{array}$ & "I & $\begin{array}{l}\text { “Dersin işlenişinde ve uygulamalarda görsel iletişim araçlarına yer verilmeli; } \\
\text { slayt, bilgisayar, televizyon, etkileşimli tahta, internet, EBA içerikleri vb. etkin } \\
\text { olarak kullanılmalıdır.” }\end{array}$ \\
\hline $\begin{array}{l}\text { Medya } \\
\text { Okuryazarlığ } 1\end{array}$ & "i & $\begin{array}{l}\text { "İnternet, sinema ve televizyonun verdiği iletileri değerlendirmeleri sağlanır.” } \\
\text { “Medya metinlerinin hedef kitlesi ve amacının sorgulanması sağlanır.” }\end{array}$ \\
\hline $\begin{array}{l}\text { Esneklik ve } \\
\text { Uyum }\end{array}$ & “ & $\begin{array}{l}\text { “Özel öğretime ihtiyaç duyan öğrenciler için, bireysel özellikleri ve } \\
\text { performansları doğrultusunda Türkçe Dersi Öğretim Programı temel alınarak } \\
\text { “Bireyselleştirilmiş Eğitim Programı” hazırlanmalı ve uygulanmalıdır.” }\end{array}$ \\
\hline Girişimcilik & 6 & $\begin{array}{l}\text { "Öğrenciler, yazdıklarını sınıf ve okul panosu gibi farklı ortamlarda } \\
\text { paylaşmaya teşvik edilir.” }\end{array}$ \\
\hline Öz Yönlendirme & " & $\begin{array}{l}\text { "Öğrencilerin konu ve ana fikri belirlemeleri, buna göre giriş, gelişme, sonuç } \\
\text { bölümlerinden oluşan bir metin taslağı oluşturmaları, bu bölümlerde } \\
\text { yazacaklarını belirlemeleri sağlanır." }\end{array}$ \\
\hline $\begin{array}{l}\text { Sosyal ve } \\
\text { Kültürler Arası } \\
\text { Etkileşim }\end{array}$ & "il & $\begin{array}{l}\text { “Öğrencilerin öğrendiklerini yaşadıkları sosyokültürel ve çevresel durumlarla } \\
\text { ilişkilendirmelerine imkân sağlayan aktif olarak katılabileceği etkinlik ve } \\
\text { çalışmalara yer verilmelidir.” }\end{array}$ \\
\hline Üretkenlik & " & $\begin{array}{l}\text { “Öğrencilerin konu ve ana fikri belirlemeleri, buna göre giriş, gelişme, sonuç } \\
\text { bölümlerinden oluşan bir metin taslağı oluşturmaları, bu bölümlerde } \\
\text { yazacaklarını belirlemeleri sağlanır.” }\end{array}$ \\
\hline
\end{tabular}




\begin{tabular}{lll}
\hline $\begin{array}{l}\text { Hesap } \\
\text { Verebilirlik }\end{array}$ & 1 & $\begin{array}{l}\text { "Dijital kaynakların, özellikle internetten indirilen materyallerin kullanımında } \\
\text { intihal yapılmamalı, etik kurallara ve telif haklarına uyulmalıdır." }\end{array}$ \\
\hline $\begin{array}{l}\text { Liderlik ve } \\
\text { Sorumluluk }\end{array}$ & 2 & $\begin{array}{l}\text { "Öğrenciler kendi öğrenmelerinin sorumluluğunu almaları konusunda teşvik } \\
\text { edilmelidir." }\end{array}$ \\
Alma & & \\
\hline
\end{tabular}

Tablo 4'e göre 2018 ortaokul Türkçe Dersi Öğretim Programı'nın öğrenme-öğretme süreçlerinde 21. yüzyıl becerilerinden; eleştirel düşünme becerisine yönelik 14, üretkenlik becerisine yönelik 10, öğrenmeyi öğrenme ve medya okuryazarlığına yönelik 9, yaratıcılık, iletişim, sosyal ve kültürler arası etkileşim, öz yönlendirme ve iş birliği becerilerine ilişkin 7, girişimciliğe yönelik 6, bilgi okuryazarlığı, bilgi ve iletişim teknolojileri okuryazarlığı için 5, karar verme becerisine yönelik 5, problem çözme becerisine yönelik 3 ve yenilikçilik, esneklik ve uyum, liderlik ve sorumluluk alma becerisine yönelik 2 ve hesap verebilirlik becerisine yönelik 1 ifadeye yer verildiği görülmektedir. Buna göre öğrenme-öğretme süreçlerinde en fazla yer verilen beceriler eleştirel düşünme, üretkenlik, öğrenmeyi öğrenme ve medya okur-yazarlığı iken, en az yer verilenler hesap verebilirlik ve yenilikçilik, esneklik ve uyum, liderlik ve sorumluluk alma becerileri olmuştur. Öğrenme-öğretme süreçleri açısından en az yer verilen beceriler yaşam ve kariyer becerileridir. Öğrencilerin Türkçe dersinde verileri toplaması, organize etmesi, dinlediğini/izlediğini sorgulaması, konu ve ana fikri belirlemesi, kompozisyon yazması başka bir deyişle öğrenme sürecine aktif bir biçimde katılması ve üretken olması beklenmektedir. Öğrenme-öğretme süreçlerinde yer alan açıklamalar incelendiğinde eleştirel düşünme, karar verme, problem çözme ve öğrenmeyi öğrenme gibi üst düzey düşünme becerilerini geliştirici etkinliklere yer verilmesi gerektiği anlaşılmaktadır. Etik kurallara uyulması, öğrencilerin bireysel özelliklerini dikkate alan bireyselleştirilmiş eğitim programı uygulanması ve öğrencilerin sorumluluk almaları ile ilgili ise daha az açılama bulunduğu görülmektedir.

\section{Türkçe Dersi Öğretim Programı'nın Ölçme-Değerlendirme Sürecinde 21. Yüzyıl Becerilerine Yer} Verilme Durumu Nedir?

21. yüzyıl becerilerine Türkçe Dersi Öğretim Programı'nın ölçme ve değerlendirme sürecinde yer verilme durumu Tablo 5'te gösterilmiştir. Türkçe Dersi Öğretim Programı'nda ölçme ve değerlendirme süreçlerinin ortaokul düzeyini kapsayan bölümü 4-8. Sınıflar şeklinde verilmiş olup sınıf ayrımı yapılmadığı için tabloda da sınıf ayrımı yapılmamıştır. Programda yer alan ölçmedeğerlendirme önerilerinin tamamına değil, seçilmiş örneklerine yer verilmiştir.

Tablo 5. Ortaokul Türkçe Dersi Öğretim Programı'nın Ölçme Değerlendirme Süreçlerinde 21. Yüzyıl Becerilerine Yer Verilme Durumu

\begin{tabular}{lll}
\hline Beceriler & $\begin{array}{l}\text { Yer Verilme } \\
\text { Durumu/İfade } \\
\text { Sayısı }\end{array}$ & Örnekler \\
\hline $\begin{array}{l}\text { Problem } \\
\text { Çözme }\end{array}$ & 2 & "Akıl yürütme, uzamsal becerileri kullanmalarını sağlayacak sorular olmalıdır." \\
\hline Yaratıcılık & 3 & $\begin{array}{l}\text { "Hazırlanan maddeler, mümkün olduğunca yazılı (kısa metin, şiir, tablo, grafik vb.) } \\
\text { ve görsel unsurlar (karikatür, fotoğraf, resim vb.), grafik düzenleyiciler (kavram }\end{array}$ \\
\hline
\end{tabular}




\begin{tabular}{|c|c|c|}
\hline & & $\begin{array}{l}\text { haritaları, zihin haritaları vb.) gibi öncüllere yer verilerek zenginleştirilmeli ve } \\
\text { bunların aktif kullanımlarını gerektirmelidir." }\end{array}$ \\
\hline Yenilikçilik & 2 & $\begin{array}{l}\text { "Gerçek hayata ait durumların ve materyallerin kullanıldığı öncüllere dayalı sorular, } \\
\text { öğrencilerin çıkarım yapma becerisini yordarken edindikleri bilgileri nerede ve/veya } \\
\text { hangi gerçek hayat durumlarında kullanabileceklerine dair farkındalık } \\
\text { geliştirmelerini de sağlayacaktır." }\end{array}$ \\
\hline İletişim & 1 & $\begin{array}{l}\text { "Duyuşsal becerilerin; iş birliği yapma, çevresindeki kişilere saygıll davranma, } \\
\text { etkinliklere aktif katılma vb. gözlemlenmesine imkân sağlayan ölçütlere de yer } \\
\text { verilmelidir." }\end{array}$ \\
\hline İş Birliği & 1 & $\begin{array}{l}\text { "Duyuşsal becerilerin; iş birliği yapma, çevresindeki kişilere saygılı davranma, } \\
\text { etkinliklere aktif katılma vb. gözlemlenmesine imkân sağlayan ölçütlere de yer } \\
\text { verilmelidir." }\end{array}$ \\
\hline $\begin{array}{l}\text { Eleştirel } \\
\text { Düşünme }\end{array}$ & 3 & $\begin{array}{l}\text { "Çıkarımda bulunma, eleştirel düşünme, analiz etme becerilerini kullanacakları } \\
\text { sorular hazırlanmalıdır." }\end{array}$ \\
\hline Karar Verme & 2 & $\begin{array}{l}\text { "Yazılı sınavlar yapılandırılırken öğrencilerin üst düzey bilişsel becerilerinin } \\
\text { kullanılmasına imkân sağlayan çeşitli madde türlerinden yararlanılmalıdır." }\end{array}$ \\
\hline $\begin{array}{l}\text { Öğrenmeyi } \\
\text { Öğrenme }\end{array}$ & 4 & $\begin{array}{l}\text { "Öğrenci düzeyine uygun, öğrenmeyi pekiştirirken aynı zamanda yapmaktan zevk } \\
\text { alabileceği performans çalışmaları ve projeler de bu sınıf düzeylerinde ögrencilerin } \\
\text { bilişsel, psikomotor ve duyuşsal becerilerinin ölçülmesinde tanı amaçlı } \\
\text { kullanılabilir." }\end{array}$ \\
\hline $\begin{array}{l}\text { Bilgi } \\
\text { Okuryazarlığ } 1\end{array}$ & 1 & "Sorular eski ve yeni bilgilerin birleştirilmesini sağlamalıdır." \\
\hline $\begin{array}{l}\text { Bilgi ve İletişim } \\
\text { Teknolojileri } \\
\text { Okuryazarlığ }\end{array}$ & 2 & $\begin{array}{l}\text { "Hazırlanan maddeler Görsel unsurlar (karikatür, fotoğraf, resim vb. gibi), grafik } \\
\text { düzenleyiciler_(kavram haritaları, zihin haritaları gibi) öncüllere yer verilerek } \\
\text { hazırlanmalıdır." }\end{array}$ \\
\hline $\begin{array}{l}\text { Medya } \\
\text { Okuryazarlığ } 1\end{array}$ & 3 & $\begin{array}{l}\text { "Hazırlanan maddeler Görsel unsurlar(karikatür, fotoğraf, resim vb. gibi), grafik } \\
\text { düzenleyiciler (kavram haritaları, zihin haritaları gibi) öncüllere yer verilerek } \\
\text { hazırlanmalıdır." }\end{array}$ \\
\hline $\begin{array}{l}\text { Esneklik ve } \\
\text { Uyum }\end{array}$ & 1 & $\begin{array}{l}\text { "Gerçek hayata ait durumların ve materyallerin kullanıldığı öncüllere dayalı sorular, } \\
\text { öğrencilerin çıkarım yapma becerisini yordarken edindikleri bilgileri nerede ve/veya } \\
\text { hangi gerçek hayat durumlarında kullanabileceklerine dair farkındalık } \\
\text { geliştirmelerini de sağlayacaktır." }\end{array}$ \\
\hline Girişimcilik & 2 & $\begin{array}{l}\text { "Çaba harcama gibi becerilerin gözlemlenmesine imkân sağlayan ölçütlere de yer } \\
\text { verilmelidir." }\end{array}$ \\
\hline $\begin{array}{l}\text { Öz } \\
\text { Yönlendirme }\end{array}$ & 3 & $\begin{array}{l}\text { "Öğrencilerin kendi öğrenmelerinin sorumluluğunu almalarında öz değerlendirme } \\
\text { becerisini edinmeleri önemli bir rol oynamaktadır." }\end{array}$ \\
\hline $\begin{array}{l}\text { Sosyal ve } \\
\text { Kültürler } \\
\text { Arası } \\
\text { Etkileşim }\end{array}$ & 1 & $\begin{array}{l}\text { "Gerçek hayata ait durumların ve materyallerin kullanıldığı öncüllere dayalı sorular, } \\
\text { öğrencilerin çıkarım yapma becerisini yordarken edindikleri bilgileri nerede ve/veya } \\
\text { hangi gerçek hayat durumlarında kullanabileceklerine dair farkındalık } \\
\text { geliştirmelerini de sağlayacaktır." }\end{array}$ \\
\hline Üretkenlik & 2 & $\begin{array}{l}\text { "Dil becerilerinin ayrı ayrı veya bütüncül bir şekilde değerlendirilebilmesi için eğitim } \\
\text { öğretim yılı sürecinde öğrenci ürün dosyaları ile elektronik portfolyolardan da } \\
\text { yararlanılabilir." }\end{array}$ \\
\hline $\begin{array}{l}\text { Hesap } \\
\text { Verebilirlik }\end{array}$ & 2 & $\begin{array}{l}\text { "...sorumluluklarını yerine getirme gibi duyuşsal becerilerin gözlemlenmesine } \\
\text { imkân sağlayan ölçütlere yer verilmelidir." }\end{array}$ \\
\hline $\begin{array}{l}\text { Liderlik ve } \\
\text { Sorumluluk } \\
\text { Alma }\end{array}$ & 1 & $\begin{array}{l}\text { “...sorumluluklarını yerine getirme gibi duyuşsal becerilerin gözlemlenmesine } \\
\text { imkân sağlayan ölçütlere yer verilmelidir." }\end{array}$ \\
\hline
\end{tabular}

Tablo 5'e göre ortaokul Türkçe Dersi Öğretim Programı'nın ölçme-değerlendirme süreçlerinde en fazla yer verildiği saptanan beceriler öğrenmeyi öğrenme, öz-yönlendirme, medya okur-yazarlığ1 eleştirel düşünme ve yaratıcılık iken, en az yer verilenler iletişim, sosyal ve kültürler arası etkileşim, iş birliğgi, bilgi okuryazarlı̆̆ı, esneklik ve uyum ve liderlik ve sorumluluk almadır. Öğrencilerin öğrenmeyi öğrenme düzeylerini, yaratıcılıklarını ve eleştirel düşünme becerilerini ortaya çıkarabilecek 
bilişsel soruların yanında, duyuşsal ve psiko-motor becerilere yönelik ölçme-değerlendirme yapılmasına yönelik önerilerin bulunduğu görülmektedir. Programın ölçme-değerlendirme süreçleri ögesinde bilişsel alan ağırlıklı ve üst düzey düşünme becerilerinin ölçülmesine yönelik bir vurgunun olduğu söylenebilir. Ancak programın kazanımları ve içeriğinde fazlaca vurgulanan iletişim ve iş birliği becerilerine yönelik ölçme-değerlendirme önerilerinin yetersiz olması, programın önemli bir eksiği olarak değerlendirilmiştir. Bilgi okur-yazarlı̆̆ı becerisi ise kazanım ve içerikte olduğu gibi ölçme-değerlendirmede en az yer verilen becerilerden birisi olarak dikkati çekmektedir.

\section{Sonuç ve Tartışma}

21. yüzyıl becerileri açısından ortaokul Türkçe Dersi Öğretim Programı́nın ögelerinin incelendiği bu çalışmada, programda en çok ve en az yer verilen 21. yüzyıl becerileri Tablo $6^{\prime}$ da özetlenmiştir.

Tablo 6. Ortaokul Türkçe Dersi Öğretim Programı́nın Ögelerinde 21. Yüzyıl Becerilerine Yer Verilme Durumu

\begin{tabular}{|c|c|c|c|c|}
\hline & $\begin{array}{l}\text { Yetkinlik, Amaç ve } \\
\text { Kazanımlar }\end{array}$ & İçerik & $\begin{array}{l}\text { Öğrenme-Öğretme } \\
\text { Süreçleri }\end{array}$ & $\begin{array}{l}\text { Ölçme- } \\
\text { Değerlendirme } \\
\text { Süreçleri }\end{array}$ \\
\hline En Çok & $\begin{array}{l}\text { İletişim, } \\
\text { Eleştirel düşünme, } \\
\text { Karar verme, } \\
\text { üretkenlik }\end{array}$ & $\begin{array}{l}\text { İletişim, } \\
\text { İş birliği, problem } \\
\text { çözme, yaratıcılık, } \\
\text { Sosyal ve kültürler } \\
\text { arası etkileşim, } \\
\text { üretkenlik }\end{array}$ & $\begin{array}{l}\text { Eleştirel düşünme, } \\
\text { üretkenlik, medya } \\
\text { okuryazarlığı, } \\
\text { öğrenmeyi öğrenme }\end{array}$ & $\begin{array}{l}\text { Öğrenmeyi } \\
\text { öğrenme, medya } \\
\text { okuryazarlığı, } \\
\text { eleştirel düşünme, } \\
\text { yaratıcıllk, } \\
\text { Öz yönlendirme }\end{array}$ \\
\hline En $\mathrm{Az}$ & $\begin{array}{l}\text { Yenilikçilik, } \\
\text { İş birliği, Medya } \\
\text { okuryazarlığı, bilgi } \\
\text { okur-yazarlığı, } \\
\text { girişimcilik, liderlik } \\
\text { ve sorumluluk alma }\end{array}$ & $\begin{array}{l}\text { Eleştirel düşünme, } \\
\text { Karar verme, medya } \\
\text { okuryazarlı̆̆ı, } \\
\text { öğrenmeyi } \\
\text { öğrenme, } \\
\text { yenilikçilik, } \\
\text { esneklik ve uyum }\end{array}$ & $\begin{array}{l}\text { Hesap verebilirlik, } \\
\text { liderlik ve } \\
\text { sorumluluk alma, } \\
\text { yenilikçilik, esneklik } \\
\text { ve uyum }\end{array}$ & $\begin{array}{l}\text { İletişim, } \\
\text { İş birliği, Bilgi } \\
\text { okuryazarlığı, } \\
\text { esneklik ve uyum, } \\
\text { liderlik ve } \\
\text { sorumluluk alma }\end{array}$ \\
\hline
\end{tabular}

Türkçe Dersi Öğretim Programı́nın kazanımlarında en fazla öğrenme ve yenilikçilik becerilerine yer verildiği, onu yaşam ve kariyer becerilerinin izlediği, en az yer verilen beceri grubunun ise bilgi, medya ve teknoloji becerileri olduğu belirlenmiştir. Buna göre Türkçe programının kazanımlarının 21. yüzyıl becerileri açısından dengeli bir dağılıma sahip olmadığı söylenebilir. Kurudayığlu ve Sosyal'ın (2019) 2018 Türkçe (1-8. sınıf); Kayhan vd.'nin (2019), sekizinci sınıf 2018 Türkçe öğretim programını incelediği çalışmalarda da benzer sonuçlarla karşılaşılmış, 21. yüzyıl becerilerinin programın amaç ve kazanımlarında belli becerilere yoğunlaştığı saptanmıştır. Başka bir deyişle 2018 Türkçe programının tamamı için benzer bir yorum yapılabilir.

Program kazanımlarında en fazla ilişkilendirilen beceri ise iletişim olmuştur. Dökmen (2004) iletişimi "bilgi üretme, aktarma ve anlamlandırma süreci" olarak tanımlamaktadır. Çetinkaya'ya (2011) göre ise iletişim, "genel olarak en az iki kişi arasındaki duygu, düşünce, tasarı, izlenim, bilgi 
paylaşımı, etkileşimdir." İletişim becerisinin belli aşamalardan geçmesi, geliştirilmesi ve olgunlaştırılması gereklidir. Eğitimin başı başına bir iletişim etkinliği olduğu söylenebilir. Çünkü eğitim öğretim ortamları iletişim üzerine kuruludur (Zevfi, 2015). Kurudayığlu ve Çetin (2015) bireylerin istenilen nitelikte iletişim becerilerine sahip olmalarının ancak eğitim ile mümkün olabileceğini ve bireyin sosyal, akademik ve özel yaşamının sahip olduğu iletişim becerilerine göre şekilleneceğini belirtmektedir. Bu açıdan bakıldığında iletişim becerilerinin geliştirilmesi için Türkçe dersi önemli bir yere sahiptir. Türkçe dersi kazanımları dinleme, konuşma, okuma, yazma öğrenme alanlarına göre gruplandırılmıştır (MEB, 2018). “Ana dilde iletişim yetkinliği, duygu ve düşünceleri ile bir konudaki görüşlerini veya tezini sözlü ve yazılı olarak etkili ve anlaşılır biçimde ifade etmelerinin sağlanması; dinleme/izleme, konuşma, okuma ve yazma becerilerinin geliştirilmesi" özel amaçları düşünüldüğünde Türkçe dersinin doğasının yazılı ve sözlü iletişim üzerine kurulu olduğu görülür. Bireyler dil ile düşünür, gelen uyarıcıları anlamlandırır, zihnindekileri başkasına aktarır ve dil sayesinde düşünce gücünü geliştirir (Aksan, 2015; Ergin, 2013; Özbay, 2013). Bu nedenle kazanımların üçte birine yakınının iletişim becerisiyle ilişkili ve en fazla yer verilen becerinin iletişim becerisi olması doğal bir sonuç olarak değerlendirilmiştir. Literatürdeki diğer doküman analizi çalışmalarında da, Türkçe Dersi Öğretim Programı'nın kazanımlarında en fazla iletişim becerisine yer verildiği bulgulanmıştır (Belet-Boyacı ve Güner-Özer, 2019; Kayhan vd., 2019).

Türkçe Dersi Öğretim Programı́nın kazanımlarında en fazla yer verilen diğer beceriler, eleştirel düşünme, üretkenlik ve karar verme becerisidir. Eleştirel düşünme ve üretkenlik becerileri toplam kazanımların yaklaşık dörtte biri kadardır. Ayrıca eleştirel düşünme becerisi 5-6. sınıflarla kıyaslandığında 7-8. sınıflarda daha fazla yer bulmaktadır. Türkçe dersinin yapısı düşünüldüğünde öğrencilerin konuşma, dinleme, yazma ve okuma becerilerini sergilerken sürekli üretim içinde oldukları ve eleştirel düşündükleri görülmektedir. Kurudayıoğlu ve Çetin (2015) dört temel dil becerisi olan okuma, dinleme, konuşma, yazma ile bağlantılı olarak Türkçe öğretim programında yer alan temel becerilerin (Türkçeyi doğru, güzel ve etkili kullanma, eleştirel düşünme, yaratıcı düşünme, iletişim kurma, problem çözme, karar verme, bilgi teknolojilerini kullanma, araştırma, girişimcilik) geliştirilebileceğini vurgulamaktadır. Türk Dil Kurumu ([TDK], 2020) sözlüğe göre üretkenlik; üretken olma durumu, verilen emeğe ve yapılan masrafa oranla üretilen miktar, ürün verme gücü, prodüktivite anlamına gelmektedir. Trilling ve Fadel'e (2009) göre öğrencilere üretkenlik becerileri kazandırabilmek için öğrencilerin hedeflerini oluşturması, yapılması beklenen işleri önem sırasına koyması ve zamanı etkili kullanması gerekmektedir. Öğrenciler bu becerileri kazandığında proje yönetiminde de başarılı olmaktadır. Hotaman'a (2019) göre, eleştirel düşünme bireylerin farkında olarak veya olmadan gerçekleştirdiği zihinsel bir aktivite olup, eleştirel düşünme becerisi okullarda ve aile çevresinde eğitim süresince geliştirilebilir. Seferoğlu ve Akbıyık (2006) eleştirel düşünme 
becerisinin çağdaş eğitim programlarının hedefleri arasında olması ve öğrenme sürecinde temel konumda bulunması gerektiğini belirtmektedir. Zevfi (2015), Öztürk (2018) ve Söylemez'in (2018), Kurudayığlu ve Soysal'ın (2019) çalışmalarında ortaya konan, Türkçe Dersi Öğretim Programı'ndaki kazanımların eleştirel düşünme becerisi bakımından zengin olduğu, Türkçe ders kitaplarında eleştirel düşünme becerisinin diğer temel becerilere oranla daha yoğun olduğu sonuçları da araştırmanın bulgularını desteklemektedir. Tüm sınıf düzeylerinde kazanımların yaklaşık üçte birinde karar verme becerisine yer verildiği bulgusuna ulaşılmıştır. Öğrenciler kendini yazılı ve sözlü ifade etme, çıarımlarda bulunma, metinle ilgili sorular sorma vb. (metnin ana fikrini bulma, metne başlık belirleme, metinle ilgili sorunlara çözüm üretme, metinleri analiz etme gibi) kazanımlar için karar verme becerisine ihtiyaç duymaktadır.

Programın kazanımlarında en az yer bulabilen 21. yüzyıl becerileri ise iş birliği, yenilikçilik, medya okur-yazarlığı, liderlik ve sorumluluk almadır. Kazanımlar incelendiğinde iş birliği becerisinin tüm sınıf düzeylerinde \%7-8 yer bulabildiği görülmüştür. P21'e (2015) göre iş birliği becerileri; farklı takımlarda etkin ve saygılı çalışma becerisi, ortak hedefe ulaşmak için gerekli durumlarda esneklik ve diğerlerine yardım etme istekliliği, ortak çalışmada sorumluluk paylaşımı ve her takım üyesinin katkısını değerlendirme olarak sıralanmıştır. Türkçe derslerinde iletişim becerisi gibi iş birliği becerisinin de yeri oldukça fazladır. Dört temel becerinin geliştirilmesi için grup çalışmaları ve işbirlikli öğrenme sıklıkla kullanılmaktadır. $\mathrm{Bu}$ nedenle programda iş birliği becerisi ile ilişkilendirilmiş kazanım sayısının daha fazla olması beklenmektedir.

İşbirliği becerisi gibi, yenilikçilik ve medya okuryazarlığı becerilerine de program kazanımlarında oldukça az yer verilmiştir. Belet-Boyacı ve Güner-Özer'in (2019) de çalışmalarında 2017 ve 2018 Türkçe dersi programlarının kazanımlarında yenilikçilik becerilerine az yer verildiğini bulgulamıştır. 5. ve 6. sınıf kazanımlarının yaklaşık \%7'si, 7. ve 8. sınıf kazanımlarının ise yaklaşık \%9'u medya okuryazarlığı becerisine ayrılmıştır. Medya ile iç içe olan çocukların kazanmaları gereken en önemli becerilerden birinin de medya okuryazarlığı olması gerekmektedir. Bilgi okuryazarlığını yansıtan kazanımlara ayrılan yüzdenin de sınıf bazında \%8 ile \%10 arasında değiştiği görülmektedir. Bilgiye ulaşmanın çok kolay olduğu günümüzde öğrencilerin doğru ve bilimsel bilgiye ulaşabilmeleri için kazanmaları gereken 21. yüzyıl becerilerden biri de bilgi okuryazarlığıdır. Bu nedenlerle programda bilgi, medya ve teknoloji becerilerine yer verildiği ancak bunun yeterli olmadığ söylenebilir. Gelecek nesillerin 21. yüzyıl için gerekli becerileri kazanmasını sağlamada öncülük eden bir kuruluş olan EnGauge'e (2003) göre teknoloji dünyanın çalışma şeklini değiştirir. Teknoloji geliştikçe onu kullananların beceri setleri de gelişmelidir. Yarının dünyasında rekabetçi kalabilmek için bugünün öğrencilerinin değişikliklere kolayca uyum sağlayacak teknikler geliştirmeleri gerekmektedir. Bu kuruluş 21. yüzyıl öğrenme becerilerini “dijital çağ okuryazarlığı, yaratıcı 
düşünme becerileri, etkili iletişim, yüksek verimlilik" olarak dört grupta incelemiştir (EnGauge, 2003). Buna göre en önemli 21. yüzyıl becerilerinden birisi dijital okur-yazarlıktır. Kayhan vd.'nin (2019), çalışmasında medya okuryazarlığı ve bilgi okuryazarlığına ait kazanımların Türkçe Dersi Öğretim Programı'nda az yer aldığı; Belet-Boyacı ve Güner-Özer'in (2019) çalışmasında medya-okuryazarlığı becerisinin 2018 Türkçe dersinin kazanımlarında olmadığı ve sadece temel felsefesi ve yetkinliklerinde yer verildiği, Kurudayığlu ve Soysal'ın (2019) çalışmasında ise bilgi okuryazarlığı, medya okuryazarlığı ile bilgi ve iletişim teknolojileri okuryazarlığı becerilerine Türkçe öğretim programında yeterli düzeyde yer verilmediği, sosyal ve kültürler arası becerilerin hiç bulunmadığı sonuçlarına ulaşılmıştır. Bu sonuçlar, medya okuryazarlığı ve bilgi okuryazarlığı becerileri ile ilişkilendirilen kazanım sayılarının az olduğu bulgusunu desteklemektedir.

Türkçe Dersi Öğretim Programı'nın içeriğinde 21. yüzyıl becerilerinin tamamına yer verildiği ancak yine dengeli bir dağılımın olmadığı saptanmıştır. Belet-Boyacı ve Güner-Özer (2019) ve Bal (2018) çalışmalarında Türkçe dersi öğretim programlarının, tema ve konular bağlamında aynı düzeyde olmasa da 21. yüzyıl becerilerinin tümünü kapsayacak nitelikte olduğu sonucuna ulaşmışlardır. Bu sonuçlar da araştırmanın bulgularını desteklemektedir. Programın kazanımlarında olduğu gibi içeriğinde de en fazla yer verilen 21. yüzyıl becerisi iletişimdir. Sosyal ve kültürler arası etkileşim, iş birliği, problem çözme, yaratıcılık, üretkenlik becerilerine yönelik konuların fazla oluşu dikkat çekmektedir. Ayrıca kazanımlarda daha az yer bulan iş birliği becerisinin içerikte en fazla ilişkilendirilen 21. yüzyıl becerilerinden olduğu görülmektedir. Diğer yandan, eleştirel düşünme, karar verme, medya okuryazarlığı gibi becerilere ait tema ve konu önerilerinin az olması da düşündürücüdür. Eleştirel düşünme ve karar verme becerisine kazanımlarda oldukça fazla yer verilmesine rağmen içerikte yer bulamadığı görülmektedir. Medya okur-yazarlığı kazanımlarda olduğu gibi içerikte de en az yer verilen beceriler arasındadır. Bu araştırma sonuçlarına paralel olarak Bal (2018) Türkçe öğretim programı (1-8) ve 5. sınıf Türkçe ders kitabında en fazla iletişim ve iş birliğine, en az medya okur-yazarlığına; Kayhan vd. ise (2019), sekizinci sınıf Türkçe ders kitabında en az medya ve bilgi okur-yazarlığına ilişkin metin yer aldığını belirtmektedir.

Türkçe Dersi Öğretim Programı'nın öğrenme-öğretme yaklaşımları analiz edildiğinde öğrencilerin veri toplama, organize etme, sinıflama etkinlik önerileri ile problem çözme ve eleştirel düşünmeye; özgün metinler oluşturma, konu ve ana fikir belirleme ile yaratıcıllğa ve üretkenliğe; grup olarak yazma, dinleme, konuşma, tartışma etkinlikleri ile işbirlikli öğrenmeye; bilgi ve iletişim teknolojilerinden yararlanma ve görsel iletişim araçları kullanımı ile bilgi ve iletişim teknolojileri okur-yazarlığına vurgu yapıldığı görülmektedir. Programın öğrenme-öğretme süreçlerinde 21. yüzyıl becerilerinin tamamına yer verildiği, eleştirel düşünme, üretkenlik, medya okuryazarlığı, öğrenmeyi öğrenme gibi becerilerin öğrenme-öğretme süreçlerinde diğerlerine oranla daha fazla yer aldığı ancak 
becerilerin dağılımının diğer ögelerde olduğu gibi dengeli olmadığı görülmektedir. Başka bir deyişle öğrenme ve yenilenme becerileri programın öğrenme-öğretme süreçlerinde daha fazla ilişkilendirilirken yaşam ve kariyer becerileri kendine daha az yer bulabilmiştir. Alanyazındaki diğer çalışmaların sonucu da bu bulguyu desteklemektedir (Bal, 2018; Gültekin, 2019).

Program içeriğinde daha az yer bulan eleştirel düşünme becerisinin, kazanımlarda ve öğrenme-öğretme süreçlerinde; kazanım ve içerikte daha az yer bulan medya okur-yazarlı̆̆ becerisinin öğrenme-öğretme süreçlerinde fazla yer verilen becerilerden olması ilginç bulunmuştur. Programın kazanım, içerik ve değerlendirme ögelerinde orta düzeylerde yer alan öğrenmeyi öğrenme becerisi, programın öğrenme-öğretme süreçlerinde daha fazla vurgulanmıştır. Türkçe Dersi Öğretim Programı'nı 21. yüzyıl becerileri açısından inceleyen diğer çalışmalarda da Türkçe ders kitaplarında en fazla eleştirel düşünme (Durukan ve Demir, 2017; Kayhan vd., 2019), dijital okuryazarlık (Direkçi, Akbulut ve Şimşek, 2019), girişim ve öz-yönetim, sosyal ve kültürler arası beceriler ve bilgi, medya ve teknoloji (Belet-Boyacı ve Güner-Özer, 2019) becerilerinin kazandırılmasına yönelik etkinlikler bulunduğu saptanmıştır. Türkçe Dersi Öğretim Programı'nın öğrenme-öğretme süreçlerinde en az yer verilen 21. yüzyıl becerileri ise hesap verebilirlik, yenilikçilik, esneklik ve uyum, liderlik ve sorumluluk alma becerileridir. Belet-Boyacı ve Güner-Özer (2019), 2018 Türkçe Dersi Öğretim Programı'nın öğrenme-öğretme süreçlerine yönelik olarak yaratıcılık ile esneklik ve uyum becerilerine yönelik açıklamaların olmadığını; Gültekin (2019), kazanımlarda kendilerine fazlaca yer bulan 21. yüzyıl becerilerinin 5-8. sınıf Türkçe ders ve çalışma kitaplarındaki etkinliklerde yeterli düzeyde yer almadığını; Kayhan vd. (2019) sekizinci sınıf Türkçe ders kitabında (2018) liderlik ve sorumluluk becerisine yönelik etkinlik bulunmadığını; bilgi, medya ve teknolojilerine çok az yer verildiğini belirtmektedir.

Amerikan Ulusal Araştırma Konseyi (NRC), 2008 yılında gerçekleştirdiği bir çalıştayda 21. yüzyıl becerilerini ölçmek için birtakım önerilerde bulunmuştur. Buna göre, bu becerilerin ölçümü bilişsel (rutin olmayan problem çözme becerisi, eleştirel düşünme ve sistemli düşünme), sosyal (karmaşık iletişim, sosyal beceriler, takım çalışması, kültürel hassasiyet, karmaşıklık ile başa çıkabilme) ve içsel (öz yönetim, zaman yönetimi, kişisel gelişim, öz düzenleme, uyumluluk, yönetim) becerilere yönelik olmalıdır. 21. yüzyıl becerilerinin ölçme-değerlendirmesinde geleneksel yöntemlerin yeterli olmayacağı düşünülmektedir (Kylonen ve Bertling, 2014; Soland, Hamilton ve Stecher, 2013; Yalçın, 2018). Türkçe Dersi Öğretim Programı́nın ölçme ve değerlendirme süreçlerinde, “akıl yürütmeye dayalı, üst düzey bilişsel becerilerin kullanılmasına olanak sağlayan çeşitli madde türlerinin olması, ürün dosyaları ve e-portfolyolardan yararlanılması, yazı, görsel unsurlar ve grafik düzenleyicilerin olması, çıkarımda bulunma, eleştirel düşünme analiz etme becerilerinin kullanıldığı soruların hazırlanması" biçiminde öneriler bulunmaktadır (NRC, 2011). 
Programın ölçme değerlendirme süreçlerinde 21. yüzyıl becerilerinin tamamına eşit düzeyde olmasa da yer verildiği görülürken en fazla öğrenmeyi öğrenme becerisinin vurgulandığı bulgusuna ulaşılmıştır. Bunun dışında programda ağırlıklı olarak yer verilen diğer beceriler; eleştirel düşünme, öz yönlendirme, yaratıcılık, medya okuryazarlığı becerileri olmuştur. Ölçme değerlendirme süreçlerinde 21. yüzyıl becerileriyle ilişkilendirilme noktasında en az değinilen beceriler ise iletişim, iş birliği, esneklik ve uyum, sosyal ve kültürler arası etkileşim ve liderlik ve sorumluluk alma becerisidir. İletişim becerisi öğrenme-öğretme ve ölçme-değerlendirme süreçlerinde kazanım ve içerikte olduğu kadar çok yer bulamamıştır. İş birliği, bilgi okur-yazarlığı ile liderlik ve sorumluluk alma becerileri de ölçme-değerlendirmede az yer verilen diğer 21. yüzyıl becerileridir. Alanyazındaki diğer çalışmalarda da programın değerlendirme ögesinde problem çözme, yaratıcılık, liderlik ve sorumluluk, esneklik ve uyum ile bilgi, medya ve teknoloji becerilerine yer verilmediği görülmektedir (Belet-Boyacı ve Güner-Özer, 2019).

Türkçe Dersi Öğretim Programı'nın ögelerinde fazlaca yer bulamayan yaratıcılık, problem çözme, esneklik, girişimcilik, iş birliği çağımızda bireylerde olması en fazla beklenen becerilerdendir. Kalaycı ve Yıldırım'ın (2020) 2007, 2017 ve 2019 Türkçe programlarını karşılaştırdığı çalışmalarında, öğrencilere kazandırılması gereken becerilere 2007 programında ayrı bir başlık altında yer verildiği, 2017 ve 2019 programlarında böyle bir başlı̆̆ın olmadığı saptanmıştır. Ancak yapılan incelemede 2017 programında "Öğretim Programında Temel Beceriler" başlığı altında yaşam boyu öğrenme becerilerine yer verildiği anlaşılmaktadır. 2019 programında becerilere ayrı bir vurgunun olmamasının ve kazanımlarda örtük bir biçimde yer almalarının programların uygulanması sırasında gereken önemin verilmesini de engelleyeceği düşünülmektedir.

Sonuç olarak, programın dört ögesi düşünüldügüünde en çok yer verilen 21. yüzyıl becerilerinin öğrenme ve yenilenme, en az yer verilenlerin ise bilgi, medya ve teknoloji becerileri olduğu görülmektedir. İletişim, eleştirel düşünme, üretkenlik, karar verme becerilerinin programda genel olarak en çok yer bulan beceriler arasında olduğu; hesap verebilirlik, esneklik ve uyum, liderlik ve sorumluluk alma becerilerine ise en az yer verildiği çıkarımları yapılabilir. Başka bir deyişle programın ögelerinde 21. yüzyıl becerilerinin yer aldığı ancak her ögede farklı becerilere ağırlık verildiği ve dengeli bir dağılımın gözetilmediği söylenebilir. Oysa alanyazında belirtildiği üzere, bu becerilerin programlarda bütünlük içinde ele alınması gerekmektedir (Bal, 2018; Chu, Reynolds, Tavares, Notari ve Lee, 2017; Suto, 2013). Çalışmanın sonunda uygulamaya ve yeni araştırmalara yönelik olarak şu önerilerde bulunulmuştur:

- Türkçe Dersi Öğretim Programı́nın kazanımlarında 21. yüzyıl becerilerinin tamamına yer verildiği görülse de yer verildiği söylenen becerilerin yüzdesi oldukça düşüktür. Bu nedenle programın kazanımlarında 21. yüzyıl becerilerine daha çok yer verilmelidir. 
Ayrıca programda az yer verilen hesap verebilirlik, girişimcilik, yaratıcılık, yenilikçilik, öz yönlendirme ve öğrenmeyi öğrenme gibi becerileri kazandırmak için programın kazanımları gözden geçirilerek bu becerilere yönelik daha fazla kazanım olmalıdır.

- Türkçe Dersi Öğretim Programı́nın içeriğinde tema ve konu önerilerinin az olduğu öğrenmeyi öğrenme, eleştirel düşünme, karar verme, medya okuryazarlığı gibi becerilere daha fazla yer verilmelidir.

- 21. yüzyıl becerilerinin öğrenme-öğretme süreçlerinde uygulama düzeyini yükseltmek için uygulama düzeyinin daha az olduğu hesap verebilirlik, öğrenmeyi öğrenme, öz yönlendirme, medya okuryazarlı̆̆ı, esneklik ve uyum becerilerini kazandırıcı, destekleyici teknolojilerin kullanımını sağlayan, sorgulama ve probleme dayalı yaklaşımları ve üst düzey düşünme becerilerini birleştiren yenilikçi öğrenme etkinlikleri çoğaltılmalıdır.

- Türkçe derslerinde ölçme ve değerlendirme süreçlerinde geleneksel kalem kağıt testleri yerine etkili ve biçimlendirici sınıf değerlendirmelerinin yanı sıra yüksek kaliteli standart testler de dahil olmak üzere, öğrencilerin 21. yüzyıl becerileri yeterliliğini ölçen, teknolojiyle geliştirilmiş, biçimlendirici ve özetleyici değerlendirmeler yapılması sağlanabilir. Bu sayede öğrencilerin 21. yüzyıl becerilerini kazanıp kazanmadıkları da belirlenebilir.

- Programın dört ögesinde de az yer verilen (hesap verebilirlik, öğrenmeyi öğrenme, öz yönlendirme, medya okuryazarlığı, esneklik ve uyum) 21. yüzyıl becerilerinin başka hangi derslerde kazandırılabileceği araştırılabilir.

- Türkçe dersinden farklı olarak sosyal bilgiler, matematik, fen bilimleri, İngilizce gibi derslerin programlarının da 21. yüzyıl becerileri açısından incelenmesi önerilebilir.

- Bu araştırmada ortaokul Türkçe Dersi Öğretim Programı 21. yüzyıl becerileri doküman analizine göre incelenmiştir. Becerilere yönelik öğretmen ve öğrenci görüşlerinin alındığı, öğretmenlerin 21. yüzyıl becerileri yeterlilik düzeyleri ve algılarının incelendiği, sınıf içi gözlemlere dayalı çalışmalar yapılabilir.

\section{Kaynaklar}

Aksan, D. (2015). Her yönüyle dil ana çizgileriyle dilbilim. Ankara: Türk Dil Kurumu.

Aktaş, E., \& Yurt, S. U. (2016). 2005 ile 2015 ilköğretim Türkçe dersi öğretim programlarının (1-8. sinıflar) karşılaştırılması. 15. Uluslararası Sınıf Öğretmenliği Eğitimi Sempozyumu'nda sunulan bildiri, Muğla Sıtkı Koçman Üniversitesi, Muğla. 
Altunkeser, F., \& Coşkun, İ. (2016). 2005 ve 2015 Türkçe dersi öğretim programlarının karşılaştırılması ve değerlendirilmesi. 15. Uluslararası Sınıf Öğretmenliği Eğitimi Sempozyumu'nda sunulan bildiri, Muğla Sıtkı Koçman Üniversitesi, Muğla.

Altunkeser, F., \& Coşkun, İ. (2017). 2009 ve 2015 Türkçe dersi öğretim programlarının karşılaştırılması ve değerlendirilmesi. Trakya Üniversitesi Ĕ̆itim Fakültesi Dergisi, 8(1), 114-135.

Alver, M., \& Sancak, Ş. (2016). 2015 Türkçe dersi öğretim programı hakkında öğretmen, öğretmen adayı ve öğretim elemanı görüşleri. Turkish Studies, 11(14), 31-60.

Bağcl-Ayranc1, B., \& Mutlu, H. H. (2017). 2006, 2015 ve 2017 Türkçe dersi öğretim programlarının karşılaştırılması. International Journal of Language Academy, 5(7), 119 -130.

Bal, M. (2018). Türkçe dersinin 21. yy becerileri açısından incelenmesi, Turkish Studies, 13(4), 49-64.

Bayburtlu, Y. S. (2015). 2015 Türkçe dersi öğretim programı ve 2006 Türkçe dersi öğretim programının değerlendirilmesi. Turkish Studies, 10(15), 137-158.

Belet-Boyacı, Ş. D., \& Güner-Özer, M. (2019). Öğrenmenin geleceği: 21. yüzyıl becerileri perspektifiyle Türkçe dersi öğretim programları. Anadolu Journal of Educational Sciences International, 9(2), 708- 738 .

Büyüköztürk, Ş., Kılıç-Çakmak, E., Akgün, E. Ö., Karadeniz, Ş., \& Demirel, F. (2016). Bilimsel araştırma yöntemleri. Ankara: Pegem.

Cemiloğlu, M. (2004). Ilköğretim okullarında Türkçe öğretimi. İstanbul: Aktüel.

Chu, S. K. W., Reynolds, R. B., Tavares, N. J., Notari, M., \& Lee, C. W. Y. (2017). Twenty-first century skills and global education roadmaps. 21st century skills development through inquiry-based learning içinde (s. 17-32). Springer: Singapore.

Çetinkaya, Z. (2011). Türkçe öğretmen adaylarının iletişim becerilerine ilişkin görüşlerinin belirlenmesi. Kastamonu Ĕ̆itim Dergisi, 19(2), 567-576.

Demirel, Ö. (1999). Türkçe öğretimi. Ankara: Pegem.

Direkçi, B., Akbulut S., \& Şimşek, B. (2019). Türkçe dersi öğretim programı (2018) ve ortaokul Türkçe ders kitaplarının dijital okuryazarlık becerileri bağlamında incelenmesi, AVRASYA Uluslararası Araştırmalar Dergisi, 7(16), 797 - 813.

Dökmen, Ü. (2004). İletişim çatışmaları ve empati. İstanbul: Sistem.

Durukan, E., \& Demir, E. (2017). 6, 7 ve 8. Sınıf Türkçe dersi öğrenci çalışma kitaplarındaki etkinliklerin Bloom'un yenilenmiş taksonomisine göre sınıflandırılması. Uluslararası Türkçe Edebiyat Kültür Eğitim (TEKE) Dergisi, 6(3), 1619-1629. http://www.tekedergisi.com/Makaleler/1379543468 23durukan.pdf sayfasından erişilmiştir.

Ekici, G., Abide, Ö. F., Canbolat, Y., \& Öztürk, A. (2017). 21. yüzyıl becerilerine ait veri kaynaklarının analizi. Eğitim ve Öğretim Araştırmaları Dergisi, 6(Özel Sayı 1), 124-134. 
Epçaçan, C., \& Erzen, M. (2008). İlköğretim Türkçe dersi öğretim programının değerlendirilmesi. Sosyal Araştırmalar Dergisi, 1(4), 182-202.

$\begin{array}{llll}\text { EnGauge. (2003). } & \text { enGauge21st Skills. }\end{array}$

https://www.cwasd.k12.wi.us/highschl/newsfile1062 1.pdf sayfasından erişilmiştir.

Ergin, M. (2013). Türk dil bilgisi. İstanbul: Bayrak.

Fadel, C., Bialik, M., \& Trilling, B. (2015). Four dimension education. The competence learner need to succeed. Boston: The Center For Curriculum Redesign.

Gültekin, H. (2019). Türkçe dersi öğrenci çalışma kitaplarının 21. yüzyıl becerileri açısından incelenmesi. (Yüksek lisans tezi). https://tez.yok.gov.tr sayfasından erişilmiştir.

Hotaman, D. (2019). Ekonomik açıdan 21. yüzyıl becerileri. A. D. Öğretir-Özçelik, \& M. N. Tuğluk. (Ed). Eğitimde ve endüstride 21. yüzyıl becerileri içinde (s. 276). Ankara: Pegem.

Kalaycı, N., \& Yıldırım, N. (2020). Türkçe dersi öğretim programlarının karşılaştırmalı analizi (20092017-2019). Trakya Ĕ̆itim Dergisi, 10(1), 238-262.

Karasar, N. (2017). Bilimsel araştırma yöntemi. Ankara: Anı.

Kay, K. (2010). 21st century skills: Why they matter, what they are, and we get there. J. Bellanca, \& R. Brandt (Ed.) Rethinking how students learn içinde (s. xiii - xxxi). Bloomington: Solution TreePress.

Kayhan, E., Altun, S., \& Gürol, M. (2019). Sekizinci sınıf Türkçe öğretim programı (2018)'nın 21. yüzyıl becerileri açısından değerlendirilmesi. Adnan Menderes Üniversitesi Eğitim Fakültesi Eğitim Bilimleri Dergisi, 10(2), 20-35.

Kereluik, K., Mishra, P., Fahnoe, C., \& Terry, L. (2013). What knowledge is of most worth: Teacher knowledge for 21st century learning. Journal of Digital Learning in Teacher Education, 29(4), 127140.

Keskin, S. (2012). İnovasyon nasıl yapılır? "Yenilikçi fikir ve ürün arayanlara pratik modeller". İstanbul: Mavi.

Koenig, J. A. (2011). Assessing 21st century skills: Summary of a workshop. Washington, DC: National Research Council.

Korkmaz, G., \& Kalayc1, N. (2019). Theoretical foundations of project based curricula in higher education. Çukurova University Faculty of Education Journal, 48(1), 236- 274.

Kurudayığlu, M., \& Çetin, Ö. (2015). Temel beceriler ve Türkçe öğretimi. Ana Dili Eğitimi Dergisi, 3(3), 1-19.

Kurudayığlu, M., \& Soysal, T. (2019). 2018 Türkçe dersi öğretim programı kazanımlarının 21. yüzyıl becerileri açısından incelenmesi. Ahi Evran Üniversitesi Sosyal Bilimler Enstitüsü Dergisi, 5(2), 483-496. 
Kylonen, P. C., \& Bertling, J. P. (2014). Innovative questionnaire assessment methods to increase crosscountry comparability. L. Rutkowski, M. Von Davier, \& D. Rutkowski (Ed.), Handbook of international large scale assessment: Background, technical issues, and methods of data analysis içinde (s. 277-285). Boca Raton, FL.: CRC Press.

Lai, E. R., \& Viering, M. (2012). Assessing 21st century skills: Integrating research findings. National Council on Measurement in Education, Vancouver, BC, Canada. http://researchnetwork.pearson.com/wpcontent/uploads/Assessing 21st Century Skills NC ME.pdf sayfasından erişilmiştir.

Marzano, R. J., \& Heflebower, T. (2012). Teaching and assessing 21st century skills. Bloomington: IN: Marzano Research Laboratory.

MEB. (2005). İlköğretim Türkçe Dersi Öğretim Programı ve Kılavuzu. Ankara: Talim ve Terbiye Kurulu Başkanlığı.

MEB. (2018). Türkçe Dersi Öğretim Programı (İlkokul ve Ortaokul 1, 2, 3, 4, 5, 6, 7 ve 8. Sınıflar). Ankara: Talim ve Terbiye Kurulu Başkanlığı

Miles, M. B., \& Huberman, A. M. (1994). An expanded sourcebook: Qualitative data analysis (2nd ed.). Thousand Oaks: Sage

National Research Council. (2011). Assessing 21st century skills: Summary of a workshop: National Academies Press.

OECD. (2012). Preparing teachers and developing school leaders for the 21st century lessons from around the world. ilibrary.org/docserver/9789264174559en.pdf?expires=1525871538\&id=id\&accname=ocid430235 64\&checksum=C1612E76295F222EDFA279634267D51A sayfasından erişilmiştir.

Öz, F. (2001). Uygulamalı Türkçe öğretimi. Ankara: Anı.

Özbay, M. (2013). Türkçe özel öğretim yöntemleri I. Ankara: Öncü.

Öztürk, Y. (2018). 2015 Türkçe dersi öğretim programında yer alan anlama kazanımlarının temel becerilere uygunluğu. (Yüksek lisans tezi). https://tez.yok.gov.tr sayfasından erişilmiştir.

Partnership for 21st Century Skills - P21. (2015). P21 framework definitions. http://www.p21.org/storage/documents/P21 Framework Definitions.pdf $\quad$ sayfasından erişilmiştir.

Schleicher, A. (2012). Preparing teachers and developing school leaders for the 21st century: Lessons from around the world. Paris: OECD Publishing.

Seferoğlu, S., \& Akbıyık, C. (2006). Eleştirel düşünme ve öğretimi. Hacettepe Üniversitesi Eğitim Fakültesi Dergisi, 30(30), 193-200.

Sever, S. (2000). Türkçe öğretimi ve tam öğrenme. Ankara: Anı. 
Soland, J., Hamilton, L. S., \& Stecher, B. M. (2013). Measuring 21st century competencies guidance for educators. Santa Monica, CA: RAND Corporation.

Söylemez, Y. (2018). 2018 Türkçe dersi öğretim programındaki kazanımların üst düzey düşünme becerileri açısından değerlendirilmesi. Atatürk Üniversitesi Türkiyat Araştırmaları Enstitüsü Dergisi, 63, 345-384.

Suto, I. (2013). 21st century skills: Ancient, ubiquitous, enigmatic? Research matters: A Cambridge Assessment Publication, 15, 2-8.

Şahin, İ. (2007). Yeni ilköğretim 1. kademe Türkçe programının değerlendirilmesi. İlköğretim Online, 6(2), 284- 304 .

Şahin, D., \& Bayramoğlu, C. D. (2016). 2015 Türkçe öğretim programının metin, tür ve tema seçimi bakımından değerlendirilmesi. Turkish Studies, 11(3), 2095-2130.

Türk Dil Kurumu. (2020). Türkçe sözlük. Ankara: TDK.

Trilling, B., \& Fadel, C. (2009). 21st century skills: learning for life in our times. San Francisco: Jossey-Bass.

Wagner, T. (2008). The global achievement gap: why even our best schools don't teach the new survival skills our children need-and what we can do about it. New York: Basic Books.

Yalçın, S. (2018). 21. yüzyıl becerileri ve bu becerilerin ölçülmesinde kullanılan araçlar ve yaklaşımlar. Ankara Üniversitesi Ĕ̆itim Bilimleri Fakültesi Dergisi, 51(1), 183-201.

Yıldırım, A., \& Şimşek, H. (2018). Sosyal bilimlerde nitel araştırma yöntemleri. Ankara: Seçkin.

Yıldız, D. G., \& İzalan, Z. (2016). 2005 Türkçe dersi öğretim programı ve 2015 Türkçe dersi öğretim programının Karşılaştırılması. 15. Uluslararası Sınıf Öğretmenliği Eğitimi Sempozyumu'nda sunulan bildiri, Muğla Sıtkı Koçman Üniversitesi, Muğla. http://usos2016.com/usos2016bildiri-ozet-kitabi.pdf sayfasından erişilmiştir.

Yılmaz, E. (2016). 21. yüzyıl becerileri kapsamında dönüşen okul paradigması. E. Yılmaz. (Ed.) Eğitim bilimlerinden yansımalar içinde (s. 8-11). Konya: Çizgi. https://www.researchgate.net/publication/316105245 21yuzyil becerileri kapsaminda donus en okul paradigmasi sayfasından erişilmiştir.

Zevfi, R. (2015). Ortaokul Türkçe ders kitaplarının Türkçe dersi öğretim programında yer alan temel beceriler açısından incelenmesi. (Yüksek lisans tezi). https://tez.yok.gov.tr sayfasından erişilmiştir.

\section{Extended Summary}

Today, a lot of work done by people in the previous century can be done in a very short time thanks to technology. Being good in basic skills such as reading, writing, and mathematics does not meet the need for employees in the business world. In order to survive in the developing and changing world, 21st-century skills such as creative, critical, and original thinking, communication 
and cooperation, leadership, time management, problem solving, decision making, and innovation are needed. Studies have named these skills as 21st-century skills. Scientists from different countries have tried to identify these skills and have agreed that they should be included in educational programs. 21st-century skills are tried to be included in education programs both in the world and in our country. Eight basic skills that should be acquired by students have been included in all education programs in our country since 2005 . These skills seem to be closely related to 21 st-century skills. There are basic skills that are aimed to be acquired in common in Turkish, mathematics, science, foreign language, and social studies curriculums developed since 2005. One of the most important lessons to which 21st-century skills can be associated is Turkish because Turkish lesson improves not only basic language skills but also thinking skills. With the Turkish lesson, it is possible to discover the language and use it in an increasingly enriched line, to create aesthetic pleasure, to create a system of values, and to associate, organize and use information.

The aim of this study is to examine the 2018 secondary school (5th, 6th, 7th, and 8th grades) Turkish course curriculum in terms of 21st-century skills. Depending on this purpose, the subproblems of the research are as follows:

Secondary school Turkish course curriculum;

1. What is the suitability of 21st-century skills in its aims (specific objectives and competence)?

2. What is the suitability of 21st-century skills in its content?

3. What is the suitability of 21st-century skills in the learning-teaching process?

4. What is the suitability of 21st-century skills in the assessment and evaluation process?

In the study, a descriptive model was used to evaluate the 2018 Middle School Turkish course curriculum in terms of 21st-century skills. While the secondary school Turkish course curriculum (5th8th grades) was examined in terms of 21st-century skills, document analysis, one of the qualitative research methods, was used. Accordingly, the aims, content, learning-teaching processes, assessment, and evaluation dimensions of the Turkish teaching program were analyzed in terms of 21st-century skills. In order to examine the Secondary School Turkish Course Curriculum, the skills created by regarding the P21 classification were taken into consideration. It was decided to use the P21 classification, as it contains the most repetitive skills from different sources. These skills are grouped under the heading of learning and innovation, knowledge, media and technology, and life and career skills. In order to analyze the Turkish course curriculum in terms of 21st-century skills, a specification table has been prepared. The specifier table consists of 19 rows and 7 columns. There are 21st-century skills in the lines; competence, special objectives, achievements, theme and topic suggestions, learning-teaching processes, assessment, and evaluation in the columns. The Turkish course 
curriculum was analyzed using descriptive analysis. The stages of document analysis were followed to examine the 21st-century skills in the Turkish language curriculum. In the document analysis process, the stages of reaching the documents, checking the originality (originality), understanding the documents, analyzing the data, and using the data were followed.

It was determined that learning and innovation skills were the most used in the acquisitions of the Turkish course curriculum, followed by life and career skills, and the least used skill group was knowledge, media, and technology skills. The skills most associated with program outcomes are communication, critical thinking, decision making, and productivity; the least involved are collaboration, innovation, media literacy, leadership, and responsibility taking. Accordingly, it can be said that the aims of the Turkish program do not have a balanced distribution in terms of 21st-century skills.

It was determined that the content of the Turkish course curriculum includes all 21st-century skills, but again, there is no balanced distribution. As with the program's aims, the 21st-century skill that is most frequently used in its content is communication. It is noteworthy that there are many subjects related to social and intercultural interaction, cooperation, problem solving, creativity, and productivity skills. On the other hand, it is also thought-provoking that there are few themes and topic suggestions for skills such as critical thinking, decision-making, and media literacy.

It is seen that all 21st-century skills are included in the learning-teaching processes of the program, skills such as critical thinking, productivity, media literacy, learning to learn are more involved in learning-teaching processes than others, but the distribution of skills is not balanced as in other items. In other words, while learning and renewal skills were associated more in the learningteaching processes of the program, life and career skills were less common.

While 21st-century skills are included in the assessment and evaluation processes of the program, but not equally; it was found that learning to learn skill was emphasized the most. Apart from this, other skills that are mainly included in the program are; critical thinking, self-direction, creativity, and media literacy. The least mentioned skills in relation to 21st-century skills in assessment and evaluation processes are communication, cooperation, flexibility and adaptation, social and intercultural interaction, and leadership and taking responsibility.

As a result, it can be said that 21st-century skills are included in the elements of the program, but different skills are emphasized in each element, and a balanced distribution is not observed. However, as stated in the literature, these skills should be handled in integrity in programs. Although it is seen that all 21st-century skills are included in the acquisitions of the Turkish course curriculum, the percentage of skills said to be included is quite low. Therefore, 21st-century skills should be included in the program's aims. In addition, in order to gain skills such as accountability, 
entrepreneurship, creativity, innovativeness, self-direction, and learning to learn, which are less included in the program, the program should be reviewed, and more acquisitions should be made for these skills. In the content of the Turkish course curriculum, skills such as learning to learn, critical thinking, decision making, and media literacy, for which theme and topic suggestions are few, should be given more space. 21st-century skills in learning-teaching processes with innovative learning activities that provide less implementation level accountability, learning to learn, self-direction, media literacy, flexibility and adaptation skills, provide the use of supportive technologies, and combine inquiry and problem-based approaches and high-level thinking skills should be increased. In Turkish lessons, instead of traditional pencil and paper tests, effective and formative classroom assessments, as well as high-quality standard tests, can be provided to evaluate students' 21st-century skills competence, which is developed with technology and formative and summative evaluations. In this way, it can be determined whether students have acquired 21st-century skills or not.

\section{Araştırmacıların Katkı Oranı Beyanı}

Bu makaleye araştırmacılar tarafından eşit oranda katkı sunulmuştur.

\section{Destek ve Teşekkür Beyanı}

$\mathrm{Bu}$ araştırmada herhangi bir kurum, kuruluş ya da kişiden destek alınmamıştır.

\section{Çatışma Beyanı}

Araştırmacının araştırma ile ilgili diğer kişi ve kurumlarla herhangi bir kişisel ve finansal çıkar çatışması yoktur.

\section{Etik Kurul Beyanı}

$\mathrm{Bu}$ araştırma doküman incelemesi yapılarak yürütüldüğünden etik kurul kararı gerektirmemektedir. 